\title{
O MOŻLIWOŚCI ZBAWIENIA POZA KOŚCIOŁEM Wybrane zagadnienia soteriologii św. Augustyna
}

Soteriologia św. Augustyna przyjmuje przede wszystkim postać teologii łaski ${ }^{1}$. Zbawienie jest bowiem darmowym i zupełnie niezasłużonym przez kogokolwiek darem Boga - łaską wyzwolenia człowieka z niewoli diabła, odpuszczenia grzechów, pojednania grzesznika z Bogiem oraz obdarowania go świętością ${ }^{2}$. Wszystko to jest dziełem jedynego Pośrednika pomiędzy Bogiem a ludźmi - Jezusa Chrystusa, który przyjmując na siebie przekleństwo grzechu i wydając samego siebie jako nieskalaną ofiarę, przez swoją śmierć pojednał upadłego człowieka z Bogiem ${ }^{3}$. Jednorodzony Syn w tajemnicy swego wcielenia i Paschy otworzył zatem dla wszystkich ludzi źródło łaski ${ }^{4}$, która jest udzielana przez Boga jedynie według Jego woli i dlatego żaden człowiek nie może na nią zasłużyć. Biskup Hippony podkreśla bowiem, że nie stanowi ona wynagrodzenia za dobre życie, lecz jest darmowym darem udzielanym po to, by możliwe było prowadzenie świętego życia ${ }^{5}$. Dziełem łaski jest zatem wia$\mathrm{ra}^{6}$, miłość ${ }^{7}$, każdy dobry uczynek wykonany przez człowieka ${ }^{8}$ i wytrwanie

${ }^{*}$ Ks. dr Mariusz Terka - wykładowca patrologii w Wyższym Instytucie Teologicznym w Częstochowie; e-mail: mariuszterka0@op.pl.

${ }^{1}$ Por. T. Dola, Zbawienie, w: Leksykon teologii fundamentalnej, red. M. Rusecki - K. Kaucha I.S. Ledwoń - J. Mastej, Lublin - Kraków 2002, 1359.

${ }^{2}$ Por. J.N.D. Kelly, Początki doktryny chrześcijańskiej, thum. J. Mrukówna, Warszawa 1988, 291-294.

${ }^{3}$ Por. Augustinus, De Trinitate IV 13, 17 - 14, 19, ed. A. Trapè, NBA 4, Roma 2003, 202-208, thum. M. Stokowska: Św. Augustyn, O Trójcy Świętej, POK 25, Poznań 1962, 190-194.

${ }^{4}$ Por. tenże, Enchiridion ad Laurentium. De fide, spe et caritate liber unus 28, 108, ed. E. Evans, CCL 46, Turnholti 1969, 107-108, thum. W. Budzik: Św. Augustyn, Podręcznik dla Wawrzyńca, czyli o wierze, nadziei i miłości, w: Św. Augustyn, Pisma katechetyczne, Warszawa 1952, 160.

${ }^{5}$ Por. tenże, De dono perseverantiae 12, 28-30, ed. A. Trapè - M. Palmieri - F. Monteverde, NBA 20, Roma 1987, 340-344, thum. W. Eborowicz: Św. Augustyn, Dar wytrwania, w: Św. Augustyn, Traktaty o tasce. Laska, wiara, przeznaczenie, POK 27, Poznań - Warszawa - Lublin 1970, 354-356.

${ }^{6}$ Por. tenże, De praedestinatione sanctorum (praed. sanct.) 6, 11 - 8, 16, ed. A. Trapè - M. Palmieri - F. Monteverde, NBA 20, 242-252, thum. W. Eborowicz: Św. Augustyn, Przeznaczenie świętych, POK 27, 275-280.

${ }^{7}$ Por. tenże, De gratia et libero arbitrio 17, 33 - 18, 39, ed. A. Trapè - M. Palmieri - F. Monteverde, NBA 20, 68-78, thum. W. Eborowicz: Św. Augustyn, Laska a wolna wola, POK 27, 134-139.

${ }^{8}$ Por. tenże, De gratia et libero arbitrio 6, 13, NBA 20, 40-42, POK 27, 118-120. 
w sprawiedliwym życiu ${ }^{9}$, jak również samo pragnienie łaski Bożej ${ }^{10}$, a przede wszystkim życie wieczne ${ }^{11}$.

Skoro jednak łaska jest koniecznym do zbawienia, a jednocześnie zupełnie niezasłużonym darem, to oznacza ona nie tylko pochylenie się Boga nad zagubionym człowiekiem, lecz także zwrócenie się człowieka ku Bogu ${ }^{12}$. Dlatego znajduje się ona u podstaw każdego nawrócenia jako konieczny warunek jego możliwości ${ }^{13}$. Wobec tego nie może dotyczyć ona wyłącznie tych, którzy aktualnie pozostają związani z Chrystusem więzami wiary, czyli należą do Kościoła, lecz musi rozciągać się na cały obszar ludzkości pozostającej ciągle poza widzialną strukturą chrześcijan. Odnosi się to zarówno do pogan, jak i do Żydów. Choć bowiem nie dostrzegają oni Chrystusa, gdyż patrzą na Niego jedynie oczami cielesnymi (oculi corporis) ${ }^{14}$, to przecież może On przywrócić im wzrok wiary oddziałując na ich serca ${ }^{15}$.

W tych przypadkach św. Augustyn podkreśla jednak konieczność wewnętrznego nawrócenia. Łaska Boża prowadzi bowiem zarówno pogan, jak i Żydów do wiary w Chrystusa, a tym samym do włączenia ich we wspólnotę Kościoła. Stają się oni przez to członkami struktury określonej przez Hippończyka mianem totus Christus $^{16}$, w której wcielony i uwielbiony Chrystus pełni funkcję Głowy ${ }^{17}$, zaś wszyscy z Nim związani stanowią Jego ciało (corpus Christi) ${ }^{18}$. Skoro jednak łaska, konieczna do osiągnięcia zbawienia i prowa-

\footnotetext{
${ }^{9}$ Por. tenże, De correptione et gratia 1, 1-2, ed. A. Trapè - M. Palmieri - F. Monteverde, NBA 20, 116-118, POK 27, 169-170; 6, 10, NBA 20, 128-130, POK 27, 174-176.

${ }^{10}$ Por. tamże 1, 2, NBA 20, 116-118, POK 27, 168-169.

${ }^{11}$ Por. tenże, De gratia et libero arbitrio 6, 15, NBA 20, 42-44, POK 27, 120.

${ }^{12}$ Por. tamże 5, 10, NBA 20, 36, POK 27, 116.

${ }^{13}$ Por. tamże 5, 10-12, NBA 20, 36-40, POK 27, 116-118.

${ }^{14}$ Por. tenże, Enarrationes in Ps. 134, 24, ed. D.E. Dekkers - I. Fraipont, CCL 40, Turnholti 1956, 1955, tłum. J. Sulowski, PSP 42, Warszawa 1986, 135. Słowo corpus użyte w wyrażeniu oculi corporis na określenie ziemskiego sposobu myślenia wskazuje, że nie chodzi tutaj o oczy cielesne tzn. materialne, ale na oczy cielesne w sensie przynależności do corpus diaboli. Pisze bowiem św. Augustyn (tamże) o poganach: „Nie mają oni oczu do zobaczenia tego, co kochamy”.

${ }^{15}$ Por. tenże, Enarrationes in PS. 43, 22, CCL 38, 491, PSP 38, 155; 138, 8, CCL 40, 1996-1997, PSP 42, 180; tenże, De Trinitate II 17, 28-32, NBA 4, 112-120.

${ }^{16}$ Por. tenże, Enarrationes in PS. 61, 4, CCL 39, 773-774, PSP 39, 50-51; 83, 5, CCL 39, 1150 , PSP 40, 60-61; N. Cipriani, Molti e uno solo in Cristo. La spiritualità di Agostino, Roma 2009, 115.

${ }^{17}$ Por. Augustinus, Enarrationes in Ps. 62, 2, CCL 39, 794-795, PSP 39, 74-75. Zob. W. Staniszewski, Kościót jako mistyczne ciało Chrystusa, Lublin 1936, 44-53; Cz. Bartnik, Eklezjologia, EK IV 773-781; J. Pałucki, Eklezjologia Ojców Kościoła, w: Kościót w czasach Jana Pawła II, red. M. - Rusecki - K. Kaucha - J. Mastej, Lublin 2005, 99-112; J. Edling, Rewelatywno-temporalny wymiar odkupienia w oparciu o „De civitate Dei” 'św. Augustyna, VoxP 17 (1997) z. 32-33, 233-234.

${ }^{18}$ Augustinus, Enarrationes in Ps. 39, 12, CCL 38, 434, PSP 38, 96. Por. A. Eckmann, Teologia kapłaństwa w pismach św. Augustyna, VoxP 13-15 (1993-1995) z. 24-29, 132-136; S.J. Grabowski, The Church. An Introduction to the Theology of St. Augustine, New York 1957, 8-9; T.J. Van Bavel, Chiesa, w: Agostino. Dizionario Enciclopedico, ed. A Fitzgerald, ed. italiana L. Alici - A. Pieretti, Roma 2007, 365-366.
} 
dzenia świętego życia, udzielana jest wyłącznie przez pośrednictwo Chrystusa i prowadzi do zjednoczenia z Nim, a jednocześnie jej działanie, pobudzając do nawrócenia także pogan i Żydów, nie jest ograniczone do widzialnej struktury Kościoła, to interesujące wydaje się pytanie o możliwość zbawienia wszystkich pozostających poza wiarą chrześcijańską ${ }^{19}$.

Problem ten nie należy jednak wyłącznie do teologii łaski, gdyż odwołanie się do zbawczej woli Boga, który pragnie, by wszyscy ludzie zostali zbawieni (por. 1Tm 2, 4-5), nie wystarcza do wyjaśnienia postawionego problemu. Św. Augustyn rozumie bowiem pod wyrażeniem ,wszyscy ludzie” raczej wszystkie grupy ludzi niż całą ludzkość ${ }^{20}$, która postrzegana przez perspektywę łaski, okazuje się być podzielona na dwie zasadnicze części - na tych, których Bóg wybrał i przeznaczył do zbawienia, oraz na potępioną resztę. Skoro więc Chrystus jest źródłem łaski, a obdarzenie nią prowadzi człowieka do złączenia z Nim oraz do wcielenia w Jego ciało, to zagadnienie możliwości zbawienia tych, którzy nie wierzą w Chrystusa, należałoby postawić także na gruncie eklezjologii, gdyż kwestią istotną dla omawianego problemu jest odpowiedź na pytanie: czy więzy, jakie łączą człowieka z Chrystusem, oznaczają jednocześnie przynależność do instytucjonalnego Kościoła, czy też mogą one istnieć również poza nim? Zagadnienie to przybiera tym samym postać zapytania o możliwość zbawienia poza Kościołem.

\section{POZA KOŚCIOŁEM NIE MA ZBAWIENIA}

W nauczaniu św. Augustyna znajduje się wiele miejsc, w których stwierdza on wprost i bezpośrednio, że niemożliwe jest osiągnięcie zbawienia poza Kościołem. Myśl ta jest również głęboko zakorzeniona w jego teologii. W celu ukazania głównych torów, którymi podąża myśl Hippończyka w kwestii zbawienia, należy zatem krótko przedstawić najpierw te poglądy, które podkreślają konieczność Kościoła w procesie zbawienia i uświęcania człowieka. On bowiem jest podstawową przestrzenią, w której możliwe jest spotkanie grzesznika z uświęcającą łaską Boga.

1. Zbawcze i uświęcające działanie Boga. Chrystus - Odkupiciel (redemptor) i Zbawiciel (salvator ${ }^{21}$ Kościoła wyzwala go z niewoli demonów ${ }^{22}$,

${ }^{19} \mathrm{~W}$ niniejszym artykule pominięta zostanie kwestia, czy łaska zbawienia udzielana jest wszystkim poganom, czy też jedynie niektórym, ponieważ dla określenia samej możliwości ich zbawienia nie ma to znaczenia. Zyskuje ona bowiem potwierdzenie już wówczas, gdy można znaleźć choćby jeden przypadek tego rodzaju.

${ }^{20}$ Por. Augustinus, Enchiridion ad Laurentium 27, 103, CCL 46, 104-105, thum. Budzik, s. 156. Zob. A. Solignac, Zbawienie i nawrócenie pogan w przepowiadaniu św. Augustyna, w: Kościól otwarty na ludy. Misyjna myśl Ojców Kościoła. Wybrane zagadnienia, opr. i thum. L. Nieścior, Studia i Materiały Misjologiczne 31, Warszawa 2011, 53.

${ }^{21}$ Por. Augustinus, Enarrationes in Ps. 138, 2, CCL 40, 1990, PSP 42, 173.

${ }^{22}$ Por. tamże 106, 3, CCL 40, 1571-1572, PSP 41, 110-111. 
a oczyszczając z brzydoty grzechu, obdarza pełnym zdrowiem i pięknem, czyli sprawiedliwością ${ }^{23}$. Odkupiciel jest zatem również uświęcicielem Kościoła. Ponieważ jednak dzieło zbawienia, którego dokonuje, dotyczy Jego ciała (corpus Christi), to należy uznać, że fundamentem, na którym opiera się uświęcenie Kościoła jest właśnie wydarzenie wcielenia (incarnatio) i Paschy Odwiecznego Słowa Ojca. Przyjęło Ono bowiem nie tylko ludzkie ciało (caro), lecz także ciało (corpus) pojęte jako Kościół, pozwalając, by poprzez Jego przyjście na świat oraz śmierć na krzyżu także wszyscy wierzący w Nie chrześcijanie zostali wcieleni (concorporatio) w Kościól. Stają się w ten sposób członkami ciała, którego Głową jest sam Chrystus zasiadający po prawicy Ojca ${ }^{24}$.

Jeśli zatem związek Chrystusa i Kościoła, a równocześnie samo zbawienie, dokonuje się poprzez wydarzenie wcielenia i Paschy, to uświęcające odkupienie Kościoła dokonane przez Chrystusa jest ściśle związane z samym jego istnieniem. Św. Augustyn oddaje ową myśl, posługując się obrazem Kościoła jako tuniki, którą Chrystus sporządza dla Siebie i którą się przyodziewa, obmywając ją ze wszelkiej skazy czy też plamy grzechu, oraz rozciąga na krzyżu, aby nie miała żadnej zmarszczki ${ }^{25}$.

Wobec tego słusznym wydaje się wniosek, że w takim razie świętość, będąca owocem odkupienia, przynależy do najgłębszej istoty Kościoła, bowiem jako ciało Chrystusa jest on święty świętością swojej Głowy ${ }^{26}$. W sposób obrazowy przedstawia to biskup Hippony poprzez porównanie Kościoła do księżyca, oddając istotę jego świętości w następujących słowach:

„[...] księżyc oznacza Kościół, który nie posiada własnego światła, ale jest oświecony przez Jednorodzonego Syna Bożego, który też w wielu miejscach Pisma Świętego alegorycznie jest nazwany słońcem"27.

${ }^{23}$ Por. tamże 44, 26, CCL 39, 513: „«Quoniam concupivit rex speciem tuam». Quam speciem, nisi quam ipse fecit? Concupivit speciem. Cuius speciem? Peccatricis, iniquae, impiae, qualis erat apud patrem diabolum, et apud populum suum? Non, sed de qua dicitur: Quae est ista quae ascendit dealbata? Antea ergo non erat alba, postea dealbata. Quia si fuerint peccata vestra sicut phoenicium, tamquam nivem dealbabo. «Concupivit rex speciem tuam». Quis rex? «Quia ipse est Deus tuus». [...] Deus tuus est, rex tuus est. Rex tuus, et ipse est sponsus tuus. Regi nubis Deo, ab illo dotata, ab illo decorata, ab illo redempta, ab illo sanata. Quidquid habes unde illi placeas, ab illo habes", PSP 38, 179.

${ }^{24}$ Por. tamże 3, 9, CCL 38, 11-12, PSP 37, 49.

${ }^{25}$ Por. tamże 147, 23, CCL 40, 2159: „Quomodo enim dicitur Ecclesia corpus Christi, dicitur et vestimentum Christi ipsa Ecclesia: inde est illud quod ait Apostolus: «Ut exhiberet sibi gloriosam Ecclesiam, non habentem maculam aut rugam». Ergo exhibeat sibi gloriosam Ecclesiam, non habentem maculam aut rugam; faciat sibi vestem de illa lana quam praedestinavit in nive. Adhuc in hominibus incredulis, et frigidis, et pigris, faciat vestem de hac lana. Ut abluatur a maculis, mundetur fide; ut rugam non habeat, tendatur in cruce", PSP 42, 362-363; 50, 12, CCL 38, 608, PSP 38, 281.

${ }^{26}$ Por. tamże 85, 4, CCL 39, 1179-1180, PSP 40, 90-92. Zob. E.J. Carney, The Doctrine of St. Augustine on Sanctity, Washington 1945, 62-64 i 72-83.

${ }^{27}$ Augustinus, Enarrationes in Ps. 10, 3, CCL 38, 76: ,[...] luna intellegitur Ecclesia, quod 
Dotyczy to zarówno Kościoła jako takiego, jak również poszczególnych chrześcijan, będących członkami ciała Chrystusa, a zatem stanowiących z Nim jedność w ramach struktury totus Christus. Dlatego też św. Augustyn naucza, że wszyscy chrześcijanie, którzy zostali włączeni w Kościół i stanowią razem z Głową całe ciało Chrystusa, niejako przywdziewając Go na siebie, stają się świętymi, gdyż źródłem ich świętości jest sam Chrystus, o ile pozostają członkami Jego ciała ${ }^{28}$.

Stąd też św. Augustyn, idąc za Pismem Świętym, nazywa wspólnotę wyznawców Chrystusa rodzajem wybranym (genus electum), rodem świętym (gens sancta), królewskim kapłaństwem (regale sacerdotium) oraz narodem nabytym (populus acquisitionis) i obejmującym wszystkich pragnących Chrystusa jako dobra nawet jeszcze nie osiągniętego, którzy żyli od początku istnienia ludzkości i żyć będą do końca tego świata ${ }^{29}$. Nazywa ich również błogosławionym narodem (gens beata), który Bóg sam sobie wybrał, by był Jego wyłącznym dziedzictwem ${ }^{30}$.

Uświęcające działanie Chrystusa nie jest jedynie wydarzeniem zamkniętym w przeszłości, lecz ciągle trwającym w Kościele. Jego wcielenie jest bowiem rzeczywistością wciąż aktualną, ponieważ Chrystus pozostaje Głową swojego ciała - Kościoła. Można zatem stwierdzić, że Jego wcielenie trwa nadal w Kościele. Dlatego też Chrystus wciąż w nim działa, nieustannie go uświęcając. Dzieło zbawienia raz dokonane przez Chrystusa wcielonego i cierpiącego na krzyżu, zostaje zatem rozciągnięte na czas trwania Kościoła.

Działanie Chrystusa w dziele odkupienia jest - jak podkreśla biskup Hippony - ze względu na wcielenie oraz funkcję Głowy w strukturze totus Christus, zawsze działaniem pośrednika (mediator) pomiędzy Bogiem a ludźmi. Św. Augustyn jego istotę ujmuje w następujących słowach:

„Co znaczy być Pośrednikiem pomiędzy Bogiem a ludźmi? Nie między Ojcem i ludźmi, ale pomiędzy Bogiem i ludźmi. Kim jest Bóg? Ojciec i Syn i Duch Święty. Kim są ludzie? Grzesznicy, bezbożnicy, śmiertelni. Pomiędzy wspomnianą Trójcą a słabością ludzką i nieprawością pośrednikiem został człowiek nie bezbożny, ale jednak słaby. Po to nie jest nieprawy, ażeby łączył cię z Bogiem, a po to jest słaby, aby zbliżył się do ciebie"31.

suum lumen non habeat, sed ab unigenito Dei Filio, qui multis locis in sanctis Scripturis allegorice sol appellatus est, illustrator", PSP 37, 120.

${ }^{28}$ Por. tamże 85, 4, CCL 39, 1179, PSP 40, 91. Zob. F. Drączkowski, Poza Kościołem nie ma zbawienia, Pelplin 2008, 75-78.

${ }^{29}$ Por. Augustinus, Enarrationes in Ps. 118(20), 1, CCL 40, 1729-1730, PSP 41, 290-291.

${ }^{30}$ Por. tamże 32(3), 20, CCL 38, 268, PSP 37, 318.

${ }^{31}$ Tamże 29(2), 1, CCL 38, 174: „Quid est mediatorem esse inter Deum et homines? Non inter Patrem et homines, sed inter Deum et homines. Quid est Deus? Pater et Filius et Spiritus sanctus. Quid sunt homines? Peccatores, impii, mortales. Inter illam Trinitatem et hominum infirmitatem et iniquitatem, mediator factus est homo, non iniquus, sed tamen infirmus; ut ex eo quod non iniquus, iungeret te Deo; ex eo quod infirmus, propinquaret tibi”, PSP 37, 220. Zob. H.J. Drobner, 
Pośrednictwo Chrystusa jako Głowy Kościoła jest rozpatrywane przez Hippończyka w perspektywie odkupienia, a tym samym wcielenia i Paschy $^{32}$. Oznacza ono więc nie tylko, że wszelkie łaski, które zostają udzielone Kościołowi, pochodzą od Chrystusa wcielonego ${ }^{33}$, ale również i to, że jako Pośrednik odsyła On do ostatecznego źródła uświęcenia Kościoła, którym jest Trójca Święta.

Pośrednictwo Chrystusa i aktualność dzieła uświęcania realizuje się w szczególny sposób w Kościele, który będąc miejscem udzielania łaski Bożej, sam staje się - jak można wywnioskować, chociaż sam biskup Hippony nie naucza o tym wprost - Pośrednikiem pomiędzy Bogiem a światem. Dlatego też, uczestnicząc w dziele uświęcania Chrystusa - jak pisze Hippończyk - on również zwycięża nieprzyjaciół podobnie jak Chrystus diabła ${ }^{34}$, a ponieważ jego pośrednictwo wydaje się być uczestnictwem w pośrednictwie Głowy, to jako struktura totus Christus staje się on także jedynym Pośrednikiem pomiędzy Bogiem a ludźmi ${ }^{35}$. Z tego też względu św. Augustyn podkreśla, że jak członkowie Kościoła mogą nazywać się świętymi, ponieważ czerpią świętość ze swej Głowy, tak wszyscy, którzy znajdują się poza ciałem Chrystusa Kościołem, a zatem nie uczestniczą w świętości oraz zwycięstwie Głowy, nie mogą być świętymi ${ }^{36}$. Z tego powodu określa on Kościół mianem zgromadzenia świętych, które zostało zapowiedziane i zrealizowane przez Boga. Wszyscy ci natomiast, którzy znajdują się poza Kościołem są podobni do ziarna wyrzuconego poza klepisko i skazanego na wydziobanie przez ptaki. Oznacza to, że ziarnem należącym do roli Bożej można być jedynie w Kościele, poza nim bowiem znajdują się jedynie plewy ${ }^{37}$.

Les Pères de l'Église. Sept siècles de littérature chrétienne, tłum. franc. J. Feisthauer, Paris 1999, 449; B. René, La prédestination du Christ total selon S. Augustin, Paris 1965, 17-23.

${ }^{32}$ Por. Augustinus, Enchiridion ad Laurentium 10, 34, CCL 46, 68-69, thum. Budzik, s. 104-105; tenże, Enarrationes in PS. 90(2), 1, CCL 39, 1265-1266, PSP 40, 185-186; A.J. Gil, Bóg Wcielony. Tytuly chrystologiczne w ,Enarrationes in Psalmos” św. Augustyna (Psalmy I-L), w: Tysiac imion Chrystusa. Seminarium Patrystyczne KUL 1983-1993, red. J. Pałucki, Lublin 1994, 84; Carney, The Doctrine of St. Augustine on Sanctity, s. 62-63.

${ }^{33}$ Por. Augustinus, Enarrationes in Ps. 118(19), 7, CCL 40, 1729, PSP 41, 289-290; tenże, De peccatorum meritis et remissione et de baptismo parvulorum I 15, 19, ed. A. Trapè - I. Volpi, NBA 17/1, Roma 1981, 40.

${ }^{34}$ Por. tenże, Enarrationes in Ps. 131, 3, CCL 40, 1913, PSP 42, 88.

${ }^{35}$ Por. Cyprianus, De catholicae ecclesiae unitate 6, ed. B. Bévenot, CCL 3, Turnholti 1946, 253-254; Cipriani, Molti e uno solo in Cristo, s. 97-98.

${ }^{36}$ Por. Augustinus, Enarrationes in Ps. 85, 4, CCL 39, 1179-1180, PSP 40, 91; 36(1), 4, CCL 38, 340-341, PSP 37, 393; 67, 25, CCL 39, 888, PSP 39, 177. Zob. J. Pelikan, Powstanie wspólnej tradycji (100-600), thum. M. Hoffner, Kraków 2008, 162-166; Carney, The Doctrine of St. Augustine on Sanctity, s. 77-83.

${ }^{37}$ Por. Augustinus, Enarrationes in Ps. 149, 3, CCL 40, 2179-2180, PSP 42, 385-386; tenże, De baptismo I 11, 15, ed. R.A.Markus - A. Lombardi, NBA 15/1, Roma 1998, 290; thum. A. Żurek: Augustyn z Hippony, O chrzcie, ŹMT 38, Kraków 2006, 45-46; IV 17, 24 - 18, 25, NBA 15/1, 422-424, ŹMT 38, 121-123. Koncepcja ta jest zbieżna z tezą św. Cypriana (Epistula 73, 21, 2, ed. 
Należy jednak zauważyć, że wewnętrzne działanie Boga w sercu człowieka jest również łaską udzielaną temu, kto znajduje się poza widzialną społecznością chrześcijan. Stoi ono bowiem u podstaw jego nawrócenia i zwrócenia się w stronę Kościoła, będąc $\mathrm{w}$ ten sposób pierwszym i niezbędnym elementem procesu uświęcenia człowieka. Bóg bowiem, pobudzając sumienie, wskrzesza umarłe na skutek grzechu serce ludzkie i przywołuje je do siebie, podobnie jak uczynił to Jezus w ewangelicznej scenie ukazującej przywrócenie życia Łazarzowi. Dopiero człowiek wskrzeszony wewnętrznym głosem Boga, zostaje przyprowadzony do Kościoła, gdzie poprzez wyznanie i odpuszczenie grzechów jest wyprowadzony z grobu i rozwiązany z krępujących go śmiertelnych opasek ${ }^{38}$.

To działanie Boga, realizując się w Kościele pielgrzymującym i w jego ramach oraz łącząc człowieka z Bogiem, włącza go jednocześnie do wspólnoty chrześcijan, czyniąc członkiem ciała Chrystusa. Należy zatem zauważyć, że Kościół jest naturalnym polem zbawczego i uświęcającego działania Boga.

Do głównych środków uświęcenia, którymi posługuje się Bóg w Kościele pielgrzymującym, należą - zdaniem Hippończyka - sakramenty, spośród których wyróżnia on szczególnie chrzest ${ }^{39}$. Dlatego też św. Augustyn, posługując się alegorią, rozwija porównanie Kościoła do biblijnej arki, która stała się narzędziem ocalenia Noego, jego rodziny i reprezentantów wszystkich rodzajów zwierząt. Podobnie jak arka stała się dla nich ratunkiem przed wodami potopu, tak też Kościół jest ocaleniem przed wszelkiego rodzaju złem duchowym, a zgromadzone w niej zwierzęta symbolizują powszechność Kościoła, w którym znajdują schronienie wszystkie narody świata. W tym obrazie swoją wagę mają wszystkie szczegóły biblijnej relacji z Księgi Rodzaju, dlatego też jeden z nich św. Augustyn interpretuje następująco:

„Wejście do arki było z boku - bo nikt nie wchodzi do Kościoła inaczej, niż przez sakrament odpuszczenia grzechów, ten zaś wypłynął z otwartego boku Chrystusa" ${ }^{" 0}$.

Skoro zaś wszystkie stworzenia znajdujące się poza arką zostały zgładzone wodami potopu, to - jak zauważa biskup Hippony - oznacza to, że poza Ko-

G.F. Diercks, CCL 3C, Turnholti 1996, 555): „Salus extra Eccelsiam non est”. Zob. J. Czuj, „Extra Ecclesiam salus non est”, PT 3 (1922) 205-215; J. Ratzinger, Salus extra Ecclesiam nulla est, thum. A. Morawska, „Znak” 17 (1965) z. 5(131), 611-618; J. Kracik, Poza Kościołem nie ma zbawienia. Historia pojmowania formuty, „Znak” 46 (1994) nr 5(468), 22-32; F.A. Sullivan, Salvation outside the Church? Tracing the History of the Catholic Response, New York - Mahwall 1992.

${ }^{38}$ Por. Augustinus, Enarrationes in Ps. 101(2), 3, CCL 40, 1440, PSP 40, 363.

${ }^{39}$ Por. Pelikan, Powstanie wspólnej tradycji, s. 317-323; A. Eckmann, Jan Pawet II a 1600. rocznica nawrócenia św. Augustyna, VoxP 27(2007) t. 50-51, 168.

${ }^{40}$ Augustinus, Contra Faustum Manichaeum 12, 16, ed. L. Alici - U. Pizzani - A. di Pilla - F. Monteverde, NBA 14/1, Roma 2004, 144: „Quod aditus ei fit a latere: nemo quippe intrat in Ecclesiam, nisi per Sacramentum remissionis peccatorum; hoc autem de Christi latere aperto manavit", thum. J. Sulowski: Augustyn, Przeciw Faustusowi (Księgi I-XXI), PSP 55, Warszawa 1991, s. 77. 
ściołem woda nie posiada mocy zbawczej, lecz przynosi śmierć ${ }^{41}$. Stąd analiza działania łaski Bożej oraz podkreślenie prymatu łaski nad zasługami ludzkimi prowadzi do pytania o konieczność przyjęcia sakramentu chrztu świętego w celu otwarcia możliwości zbawienia.

2. Konieczność chrztu. W chrzcie dokonuje się wyzwolenie człowieka z niewoli oraz zwycięstwo nad nieprzyjaciółmi. Dlatego obrazem chrztu pozostaje dla św. Augustyna biblijna scena przejścia narodu wybranego przez morze Czerwone w czasie wyzwolenia z niewoli egipskiej. Podobnie bowiem jak wówczas w wodach morskich zginęli wrogowie Izraela, czyli Egipcjanie, tak obecnie w wodach chrztu uświęconych krwią Chrystusa, zostają zgładzone wszystkie grzechy ${ }^{42}$. Z tego też powodu biskup Hippony nazywa chrzest ką̧ielą odrodzenia (regenerationis lavacrum), która oczyszcza serce chrześcijanina i czyni je nieskalanym, wprowadzając go na drogę życia duchowego ${ }^{43}$.

Dlatego też biskup Hippony podkreśla ważność chrztu w procesie uświęcenia człowieka i w jego ostatecznym zbawieniu ${ }^{44}$. Skoro bowiem poprzez ten sakrament Bóg oczyszcza swoich wybranych z grzechu pierworodnego i wszelkich grzechów popełnionych już z własnej woli, to pozbawienie kogoś łask z nim związanych byłoby równoznaczne ze skazaniem go na potępienie. Takie rozumowanie jest obecne w wypowiedziach biskupa Hippony również odnośnie do dzieci umierających bez chrztu, które nie mogą otrzymać daru przebywania z Bogiem na wieki ${ }^{45}$, choć nie musi to oznaczać skazania ich na wielkie cierpienia ${ }^{46}$.

Na konieczność chrztu wskazuje Hippończyk również wówczas, gdy interpretując słowa Ewangelii traktujące o zmartwychwstaniu do życia oraz o zmartwychwstaniu sądu ${ }^{47}$, stwierdza:

${ }^{41}$ Por. tamże. Zob. H. Urs von Balthasar, Sponsa Verbi, Einsiedeln 1961, 225-227.

${ }^{42}$ Por. Augustinus, Enarrationes in Ps. 106, 3, CCL 40, 1571: „Sacramento enim tamquam rubri maris, Baptismo scilicet Christi sanguine consecrato, insequentes Aegyptii, peccata delentur”, PSP 41, 110.

${ }^{43}$ Por. tamże 118(19), 7, CCL 40, 1729, PSP 41, 289-290; 85, 4, CCL 39, 1179, PSP 40, 91. Zob. Carney, The Doctrine of St. Augustine on Sanctity, s. 91-94.

${ }^{44}$ Por. Augustinus, De Genesi ad litteram X 14, 25 - 15, 26, ed. L. Carrozzi, NBA 9/2, Roma 1989, 528-530, tłum. J. Sulowski: Św. Augustyn, Komentarz słowny do Księgi Rodzaju, w: Św. Augustyn, Pisma egzegetyczne przeciw manichejczykom, PSP 25, Warszawa 1980, 306.

${ }^{45}$ Por. tenże, De peccatorum meritis I 16, 21, NBA 17/1, 42; I 22, 31 - 23, 33, NBA 17/1, 54-60; I 27, 40, NBA 17/1, 70 .

${ }^{46}$ Por. tenże, De praedestinatione sanctorum 12, 24, NBA 20, 262-264, POK 27, 286-288; tenże, De dono perseverantiae 13, 32, NBA 20, 346-348, POK 27, 357; tenże, De gratia et libero arbitrio 22, 44, NBA 20, 88-90, POK 27, 144-145.

${ }^{47}$ Por. J 5, 28-29. „Nie dziwcie się temu! Nadchodzi bowiem godzina, w której wszyscy, którzy spoczywają w grobach, usłyszą głos Jego: a ci, którzy pełnili dobre czyny, pójdą na zmartwychwstanie życia; ci, którzy pełnili złe czyny - na zmartwychwstanie potępienia”. 
„Jako tedy dwa są odrodzenia [...] Jedno wedle wiary, które się teraz przez chrzest odbywa; drugie wedle ciała, które się odbędzie w niezniszczalności przez wieki i ostateczny sąd: tak samo i dwa są zmartwychwstania: pierwsze, które teraz jest $i$ jest to zmartwychwstanie dusz, nie dopuszczające do drugiej śmierci; a drugie zmartwychwstanie, które nie teraz się odbywa, lecz będzie przy końcu świata i nie jest zmartwychwstaniem dusz, lecz ciał; i ono to przez sąd ostateczny jednych wtrąci do powtórnej śmierci, innych znów do onego życia, które śmierci nie zna" ${ }^{48}$.

Sąd ten - jak zauważa Henryk Pietras ${ }^{49}$ - dotyczy tych, którzy nie uwierzyli w Chrystusa i nie zostali obmyci wodą chrztu. W stosunku do nich posiada on znaczenie kary potępienia ${ }^{50}$. Natomiast dla wszystkich, którzy w sakramencie chrztu zostają duchowo odrodzeni i przez to stają się uczestnikami pierwszego zmartwychwstania, rozpoczyna się okres mesjańskiego millenium, który jest czasem Kościoła. W ten sposób wspólnota zbawionych zostaje utożsamiona ze społecznością członków Kościoła ${ }^{51}$. Z tej interpretacji wysnuwa H. Pietras jednoznaczny wniosek odnośnie do nauki Hippończyka o zbawieniu:

„Dla niego ci, którzy nie uwierzyli i nie zostali ochrzczeni, nie mogą być zbawieni w żadnym wypadku. Zostaną osądzeni i w zależności od uczynków skazani na takie lub inne bytowanie - zawsze poza królestwem zbawionych. Zbawienie nie jest czymś, na co można sobie zasłużyć, jest ono tylko i wylącznie darem Chrystusa, dostępnym przez chrzest"s2.

${ }^{48}$ Augustinus, De civitate Dei XX 6, ed. B. Dombart - A. Kalb, CCL 48, Turnholti 1955, 708: „Sicut ergo duae sunt regenerationes, [...] una secundum fidem, quae nunc fit per baptismum; alia secundum carnem, quae fiet in eius incorruptione atque immortalitate per iudicium magnum atque novissimum: ita sunt et resurrectiones duae, una prima, quae et nunc est et animarum est, quae venire non permittit in mortem secundam; alia secunda, quae non nunc, sed in saeculi fine futura est, nec animarum, sed corporum est, quae per ultimum iudicium alios mittit in secundam mortem, alios in eam vitam, quae non habet mortem", tłum. W. Kubicki: Święty Augustyn, Państwo Boże, Kęty 1998, 809.

49 „Jeden chrzest na odpuszczenie grzechów” - próba zrozumienia świadectw patrystycznych, w: Kościót, świat i zbawienie we wczesnym chrześcijaństwie, SACh 17 (2004) 182-183.

${ }^{50}$ Por. Augustinus, De civitate Dei XX 6, CCL 48, 706-708, thum. Kubicki, s. 808-809; 20, 9 , CCL 48, 716-717, thum. Kubicki, s. 818; tenże, In Joannis Evangelium tract. 19, 18, ed. D.R. Willems, CCL 36, Turnholti 1954, 200-201, thum. W. Szołdrski: Św. Augustyn, Homilie na Ewangelię św. Jana, w: Św. Augustyn, Homilie na Ewangelię i pierwszy list św. Jana, PSP 15/1, Warszawa 1977, 277.

${ }^{51}$ Por. H. Pietras, Kościót jako społeczność zbawionych - próba zrozumienia aksjomatu: „Poza Kościołem nie ma zbawienia”, w: Kościót starożytny - Królestwo Chrystusa i instytucja, red. F. Drączkowski - J. Pałucki - P. Szczur - M. Szram - M. Wysocki - M. Ziółkowska, Lublin 2010, 20. Warto podkreślić, że H. Pietras (Jeden chrzest na odpuszczenie grzechów, s. 182; Kościót jako społeczność zbawionych, s. 20) wskazuje w tym kontekście na błędne tłumaczenie tego fragmentu Pisma Świętego, w którym mowa jest o dwóch zmartwychwstaniach (por. J 5, 28-29), gdyż wyrażenie „zmartwychwstanie sądu” zostaje zastąpione określeniem „zmartwychwstanie potępienia". Winę za taką interpretację przypisuje z pewnym prawdopodobieństwem św. Augustynowi.

${ }^{52}$ Pietras, Jeden chrzest na odpuszczenie grzechów, s. 182-183. Por. Augustinus, De peccatorum meritis I 20, 26, NBA 17/1, 48-50. 
Tego rodzaju interpretacja myśli św. Augustyna, jakkolwiek uprawniona na podstawie licznych wypowiedzi samego Hippończyka, rozstrzygałaby negatywnie wszelką dyskusję na temat możliwości zbawienia poza Kościołem, gdyby nie to, że sam biskup Hippony nie zawsze wyraża swą myśl tak kategorycznie i jednoznacznie. Podkreśla on bowiem, że chociaż sakrament chrztu jest niezwykle ważnym elementem na drodze do zbawienia, to jednak nie jest on warunkiem wystarczającym do jego osiągnięcia. Towarzyszyć mu powinny: wiara i nawrócenie serca ${ }^{53}$. Chrzest posiadają przecież - jak podkreśla biskup Hippony - również heretycy, zarówno ci, którzy odeszli z Kościoła już jako chrześcijanie, jak i ci, którzy zostali ochrzczeni poza nim. Niemniej jednak jako znajdujący się poza Kościołem, nie mogą oni uczestniczyć w zbawieniu błogosławionych ${ }^{54}$. To samo dotyczy również chrześcijan, którzy należą wprawdzie do Kościoła, lecz swoim życiem zaprzeczają prawdom wyznawanej wiary. Do tego zatem, żeby sakrament mógł przynosić zbawcze owoce, potrzebna jest przemiana serca (mutatio cordis) $)^{55}$.

Sytuacja ta nie jest jednak argumentem świadczącym o braku konieczności chrztu, a jedynie rozszerza perspektywę, pokazując, że chrzest nie jest gwarancją zbawienia, lecz początkiem drogi. Określa ona także istnienie pewnego rodzaju kontrastu pomiędzy tym, co zewnętrzne, a rzeczywistością duchową. Różnicę tę opisuje św. Augustyn stwierdzając w polemice z donatystami:

„Ja nie mam jednak wątpliwości, by wyżej stawiać katechumena katolickiej wiary płonącego Boską miłością niż ochrzczonego heretyka. Tak samo przecież w samym [Kościele] katolickim wyżej cenimy dobrego katechumena niż złego ochrzczonego. Przez to wcale nie poniżamy chrztu, w którym zły katolik już został zanurzony, a katechumen jeszcze nie. Nie sądzimy też, by sakrament katechumena (sacramentum catechumeni) należało wyżej cenić niż sakrament chrztu tylko dlatego, że naszym zdaniem bywają katechumeni, którzy są bardziej wierzący i lepsi niż niektórzy ochrzczeni”"56.

W celu szerszego wyjaśnienia tego zjawiska biskup Hippony odwołuje się do biblijnych postaci setnika Korneliusza oraz Szymona Maga. Ten pierwszy bowiem został napełniony Duchem Świętym zanim przyjął sakrament chrztu, zaś drugi nawet po chrzcie był przeniknięty duchem nieczystym. Nie oznacza to, że chrzest nie był Korneliuszowi potrzebny, gdyż jego sprawiedliwość, chociaż godna docenienia, nie wystarcza jeszcze do otrzymania królestwa

${ }^{53}$ Por. Augustinus, De baptismo IV 22, 29, NBA 15/1, 430-432, ŹMT 38, 127.

${ }^{54}$ Por. tamże IV 1, 1, NBA 15/1, 384, ŹMT 38, 98-99.

${ }^{55}$ Por. tamże IV 2, 2, NBA 15/1, 386, ŹMT 38, 99.

${ }^{56}$ Tamże IV 21, 28, NBA 15/1, 428: „Qua in re nec ego dubito catechumenum catholicum divina caritate flagrantem haeretico baptizato anteponere; sed etiam in ipsa intus Catholica bonum catechumenum malo baptizato anteponimus: nec ideo tamen sacramento Baptismatis, quo iste nondum, ille iam imbutus est, facimus iniuriam; aut catechumeni sacramentum sacramento Baptismi praeferendum putamus, cum aliquem catechumenum aliquo baptizato fideliorem melioremque cognoscimus", ŹMT 38, 125-126. 
niebieskiego. Dlatego też - jak podkreśla Hippończyk - został do niego posłany Piotr ${ }^{57}$.

Dla św. Augustyna wydarzenie to jest dowodem na ważność sakramentu chrztu, którego nie można zaniedbać nawet wtedy, gdy człowiek doszedł już do duchowego zrozumienia i otrzymał dar Ducha Świętego ${ }^{58}$. Niemniej jednak świadczy to również o tym, że można mówić o swego rodzaju sprawiedliwości ludzi żyjących poza Kościołem i o udzielaniu im przez Boga szczególnych łask, w tym również łaski usprawiedliwienia. Przykładem tego jest dla św. Augustyna jeden ze współukrzyżowanych z Chrystusem łotrów. Nie cierpiał on przecież niewinnie, lecz odbywał słuszną karę za swoje czyny. Dlatego też biskup Hippony stwierdza:

„Cierpiał też nie dlatego, że uwierzył, ale uwierzył, gdy cierpiał. W tym zatem łotrze okazało się, co znaczą słowa Apostoła: «Sercem przyjęta wiara prowadzi do usprawiedliwienia, wyznana ustami - do zbawienia» $(\mathrm{Rz} 10$, 10), także bez widzialnie udzielonego sakramentu chrztu. Dokonuje się to w sposób niewidzialny wówczas, gdy posługę chrztu wyklucza nie pogarda religii, ale okoliczności”'59.

Dzięki temu - jak stwierdza Hippończyk - moc chrztu może zostać uzupełniona męczeństwem, wiarą i nawróceniem serca wówczas, gdy z przyczyn niezależnych od katechumena nie można celebrować sakramentu ${ }^{60}$.

Zaistniała sytuacja świadczy przede wszystkim o konieczności łaski Bożej do bycia zaliczonym do wspólnoty zbawionych, ale jest również dowodem na wyższość rzeczywistości duchowej nad czysto formalnym pojmowaniem chrztu i jego roli w zbawieniu. Łaska uzupełnia bowiem to, czego brakuje człowiekowi nie z jego winy. Prawda ta zachowuje ważność również w odwrotnej sytuacji, tzn. w przypadku, gdy ochrzczone dziecko umiera nie zdążywszy uwierzyć w Chrystusa i swymi uczynkami wyznać wiary ${ }^{61}$. Św. Augu-

${ }^{57}$ Por. tamże IV 21, 28, NBA 15/1, 430, ŹMT 38, 126.

${ }^{58}$ Por. tamże IV 22, 29, NBA 15/1, 432, ŹMT 38, 127.

${ }^{59}$ Tamże IV 22, 29, NBA 15/1, 430-432: ,[...] nec quia credidit passus est, sed dum patitur credidit. Quantum itaque valeat etiam sine visibili sacramento Baptismi, quod ait Apostolus: Corde creditur ad iustitiam, ore autem confessio fit ad salutem; in illo latrone declaratum est. Sed tunc impletur invisibiliter, cum ministerium Baptismi non contemptus religionis, sed articulus necessitatis excludit”, ŹMT 38, 127.

${ }^{60}$ Por. tamże IV 22, 29, NBA 15/1, 430: „Baptismi sane vicem aliquando implere passionem”, ŹMT 38, 127. Św. Augustyn używa w tym miejscu do wyrażenia swej myśli czasowników: implere - napełnić, zapełnić, wypełnić, dopełnić, zastąpić kogoś, zająć czyjeś miejsce (por. Plezia III 60) oraz supplere - dopełnić, wypełnić, uzupełnić, wynagrodzić, zastąpić (Plezia V 308). Gama znaczeniowa tych słów pokazuje, że nie chodzi tutaj jedynie o proste zastąpienie chrztu przez męczeństwo, lecz przede wszystkim o jego uzupełnienie i wypełnienie. Dlatego też, chociaż męczeństwo może zastąpić sakrament chrztu, to jednak chrzest domaga się wiary i nawrócenia serca, które mogą wyrazić się również w męczeństwie.

${ }^{61}$ Por. Augustinus, De baptismo IV 24, 31, NBA 15/1, 434-436, ŹMT 38, 129. 
styn, odnosząc jednak tę zasadę do dzieci, które odchodzą z tego świata zbyt wcześnie na to, aby przyjąć wiarę, stwierdza:

„W ten oto sposób okazuje się, że czym innym jest sakrament chrztu, a czym innym nawrócenie serca. Zbawienie człowieka zakłada jedno i drugie. Jeżeli natomiast brakuje jednego z tych elementów, to nie wolno nam sądzić, że brakuje także drugiego. Przecież w niemowlęciu może być sakrament chrztu bez nawrócenia serca, tak jak w łotrze było nawrócenie serca bez sakramentu chrztu. Bóg uzupełnia, czego brakowało bez ich winy, jednemu lub drugiemu" $"$.

Skoro zatem Bóg uzupełnia to, czego człowiekowi brakuje bez jego winy, to otwiera to w pewnym stopniu możliwość przyjęcia, iż św. Augustyn dopuszczał myśl o zbawieniu dzieci, które umierają bez chrztu. W takim przypadku byłby to już jakiś wyłom w absolutnym rozumieniu konieczności chrztu, chociaż wcale jej nie zaprzecza, a nawet podkreśla rolę samego chrztu.

Zasada, do której odwołuje się św. Augustyn, wymaga pewnego zaangażowania się człowieka $\mathrm{w}$ duchowe przeżywanie swej wiary. Wprawdzie pierwszorzędne znaczenie zachowuje zawsze łaska Boża, to jednak musi się ona spotkać z pozytywną odpowiedzią ze strony obdarowanego, a nawróceniu serca musi towarzyszyć wyznanie wiary realizujące się również w postaci dobrych czynów. Konieczność ta prowadzi do kolejnego zagadnienia, które wydaje się być potwierdzeniem niemożliwości zbawienia poza Kościołem, a mianowicie do sfery życia praktycznego.

3. Znaczenie dobrych uczynków poza Kościołem. Konieczność wiary do prowadzenia dobrego życia i postępu w nim ma swoje daleko idące konsekwencje. Jedynie w Kościele możliwe jest bowiem otrzymanie daru błogosławionego życia (munus beatae vitae), a poza jego granicami niemożliwe jest dobre korzystanie z łaski Bożej, a więc i prawdziwa świętośćc ${ }^{63}$. Nie jest ona bowiem skutkiem jakichkolwiek wysiłków podejmowanych przez człowieka, lecz darem łaski Bożej. Kościół okazuje się więc jedyną strukturą, w ramach której możliwa jest świętość i dobroć wiodąca człowieka do Boga. Nie można zatem - zdaniem św. Augustyna - osiągnąć świętości poza Kościołem.

Teza ta nie neguje wszelkich przejawów dobra, istniejących poza przestrzenią Kościoła, lecz wydaje się być podkreśleniem wyjątkowości źródła ludzkiej dobroci i świętości, którym może być jedynie Bóg. Hippończyk za-

${ }^{62}$ Tamże IV 25, 32, NBA 15/1, 436: „Quibus rebus omnibus ostenditur aliud esse sacramentum Baptismi, aliud conversionem cordis; sed salutem hominis ex utroque compleri: nec si unum horum defuerit, ideo putare debemus consequens esse ut et alterum desit; quia et illud sine isto potest esse in infante, et hoc sine illo potuit esse in latrone, complente Deo sive in illo, sive in isto, quod non ex voluntate defuisset", ŹMT 38, 130.

${ }^{63}$ Por. tamże IV 1, 1 -2, 2, NBA 15/1, 384-386, ŹMT 38, 98-99. 
uważa bowiem, że chrześcijanie nie są jedynymi, którzy spełniają dobre czyny, gdyż są one właściwe i możliwe do pełnienia dla całego rodzaju ludzkiego. Wielu więc spośród pogan spełnia czyny miłosierdzia karmiąc głodnych, przyjmując w gościnę wędrowców, odwiedzając chorych, pocieszając uwięzionych czy też przyodziewając nagich. Uczynki te, choć dobre same w sobie, są jednak spełniane poza Kościołem, co oznacza, że mają źródło jedynie w ciele, bowiem serce człowieka ciągle pozostaje odłączone od Boga. Z tego powodu, jeśli nie zostaną one złożone w ,gnieździe prawdziwej wiary” katolickiej, czyli w Kościele, dzięki czemu przezwyciężone zostaną pożądliwości ciała, nie mogą wydać owoców ${ }^{64}$. Ponieważ zaś same nie potrafią zbliżyć do Boga, to zostaną one - jak stwierdza Doktor łaski - zdeptane i zgniecione jako bezowocne $^{65}$. Dlatego też, powołując się na autorytet św. Pawła Apostoła oraz św. Cypriana i na jego opinię o braku możliwości zbawienia poza wspólnotą katolicką, naucza:

„ «Gdybym ciało me wystawił na spalenie, a miłości bym nie miał, nic mi nie pomoże» (1Kor 13, 3). O tym, że męczeństwo na nic się zda, gdy nie ma miłości, podobnie jak nie pomoże ono żyjącym wprawdzie w Kościele, ale bez miłości, a za to w zawiści i złości, mówi Paweł, co podkreśla Cyprian. Mimo to [tacy] mogą posiadać i udzielać prawdziwego chrztu. «Poza Kościołem nie ma zbawienia» ${ }^{66}$. Któż zaprzeczy? Dlatego właśnie cokolwiek posiada się z Kościoła, to poza nim nie służy ku zbawieniu. Co innego jednak oznacza czegoś nie posiadać, a co innego posiadać, ale bezużytecznie"

Uczynki wykonywane poza Kościołem nie posiadają więc wartości zbawczej, gdyż takie znaczenie może nadać im tylko Bóg. Jego łaska bowiem jest źródłem wszelkiego dobra, jakie człowiek może pełnić i dopiero dzięki niej ludzkie czyny nabierają wartości zasługującej na życie wieczne. Gdyby zatem Bóg cofnął swoją łaskę, człowiek skazany byłby na upadek, gdyż jego wolność nie byłaby w stanie go podnieść, a nawet byłaby przyczyną jego upadku. Dlatego też łaska Boża jest konieczna nie tylko do usprawiedliwienia człowieka, lecz także jako niezbędna pomoc w pełnieniu przez niego dobrych uczyn-

${ }^{64}$ Por. tenże, De spiritu et littera 27, 48, ed. A. Trapè - I. Volpi, NBA 17/1, Roma 1981, $322-$ 324, tłum. W. Eborowicz: Św. Augustyn, Duch a litera, PSP 19/3, Warszawa 1977, 117.

${ }^{65}$ Por. tenże, Enarrationes in Ps. 83, 7, CCL 39, 1151-1152, PSP 40, 61-63; tenże, Enchiridion ad Laurentium 28, 106, CCL 46, 106-107, thum. Budzik, s. 158-159.

${ }^{66}$ Cyprianus, Epistula 73, 21, 2, CCL 3C, 555.

${ }^{67}$ Augustinus, De baptismo IV 17, 24, NBA 15/1, 422: „Et si tradidero corpus meum ut ardeam, caritatem autem non habeam, nihil mihi prodest. Quod si propter hoc quia caritas deest, passio nihil prodest; nec illis prodest quos in invidia intus et malevolentia sine caritate vivere Paulus dicit: Cyprianus exponit: et tamen verum baptisma possunt et accipere et tradere. Salus extra Ecclesiam non est. Quis negat? Et ideo quaecumque ipsius Ecclesiae habentur, extra Ecclesiam non valent ad salutem. Sed aliud est non habere, aliud non utiliter habere", ŹMT 38, 122. Por. tenże, De peccatorum meritis III 5, 10-11, NBA 17/, 214-218 
ków ${ }^{68}$. Biskup Hippony wyjaśnia tę myśl podając przykład życia św. Pawła Apostoła, który, będąc uwięzionym i oczekując na śmierć, patrzy na swe życie i niejako podsumowując je stwierdza, że wystąpił w dobrych zawodach i stoczył dobry bój, w którym ustrzegł otrzymaną wiarę (por. 2Tm 4, 6-8). Św. Augustyn zauważa, że Apostoł nie przypisuje sobie żadnych zasług, lecz dziękuje Bogu, który dał mu zwycięstwo, gdyż zbawienie jest darem Boga, a nie zapłatą za ludzkie uczynki, z jakich ludzie mogliby się chlubić (por. Ef 2, 8-9 ${ }^{69}$. Dlatego Hippończyk stwierdza:

„Apostoł powiedział: «Nie z uczynków» (por. Ef 2, 9-10) - jako twoich, istniejących z ciebie i przez ciebie; lecz z tych, ze względu na które Bóg cię uczynił i stworzył, to bowiem wyraża się tymi słowy: «Dziełem jego jesteśmy, stworzeni w Chrystusie Jezusie» (Ef 2,10). Nie to stworzenie, przez które staliśmy się ludźmi, ma na myśli św. Paweł, lecz to, o którym mówił (oczywiście będący już człowiekiem) Psalmista: «Serce czyste stwórz we mnie Boże» (Ps 50, 12). [...] Bóg nas utworzył, to jest ukształtował i stworzył «dla dobrych uczynków», których my nie przygotowaliśmy, lecz Bóg przygotował, abyśmy je pełnili. Przeto, najmilsi, jeśli nasze dobre życie nie jest niczym innym niż łaską Bożą, to bez wątpienia i życie wieczne, będące nagrodą za dobre życie, jest łaską Bożą daną darmo"70.

Zbawienie człowieka jest zatem możliwe jedynie w Kościele, gdyż wymaga ono zjednoczenia z Chrystusem - jedynym Zbawicielem, który jako Głowa wciąż prowadzi dzieło uświęcania, posługując się do tego celu swym ciałem Kościołem. Ponieważ zaś urzeczywistnia się ono również poprzez sakramenty udzielane przez Kościół i w Kościele, a zwłaszcza poprzez chrzest, to należy uznać, że zbawcze działanie Boga w pełni realizuje się dopiero w obszarze zakreślonym przez widzialną strukturę Kościoła ${ }^{71}$. W tym sensie, w świetle powyższych analiz, należałoby uznać, że św. Augustyn odmawia udziału w zbawieniu tym, którzy znajdują się poza wspólnotą wyznawców Chrystusa. Uznanie bowiem pewnych wyjątków od tej reguły wcale jej nie zaprzecza, a nawet można uznać, że podtrzymuje jej zasadność. Niemniej jednak w perspektywie dotychczasowych rozważań trzeba zauważyć, że nie jest rzeczą zupełnie jasną, co znaczy przynależeć do Kościoła, a prymat, który przyznaje

${ }^{68}$ Por. tenże, De gratia et libero arbitrio 6, 13, NBA 20, 40-42, POK 27, 118-119.

${ }^{69}$ Por. tamże 6, 14 - 8, 20, NBA 20, 42-50, POK 27, 119-123.

${ }^{70}$ Tamże 8, 20, NBA 20, 48-50: ,[...] non ex operibus dictum, tamquam tuis ex te ipso tibi existentibus, sed tamquam his in quibus te Deus finxit, id est formavit et creavit. Hoc enim ait: Ipsius sumus figmentum, creati in Christo Iesu in operibus bonis: non illa creatione qua homines facti sumus, sed ea de qua ille dicebat, qui utique iam homo erat: Cor mundum crea in me, Deus [...]. Fingimur ergo, id est formamur et creamur in operibus bonis, quae, non praeparavimus nos, sed praeparavit Deus, ut in illis ambulemus. Itaque, carissimi, si vita bona nostra nihil aliud est quam Dei gratia, sine dubio et vita aeterna, quae bonae vitae redditur, Dei gratia est", POK 27, 123; por. tenże, De Genesi ad litteram IV 17, 29, NBA 9/2, 190-192, PSP 25, 179; VIII 12, 27, NBA 9/2, 420, PSP 25, 265.

${ }^{71}$ Por. tenże, De peccatorum meritis III 11, 19, NBA 17/1, 230. 
Hippończyk rzeczywistości duchowej nad cielesnością i instytucją, otwiera szersze pole badawcze rozważanego zagadnienia. Przyjrzenie się temu problemowi jest konieczne dla pełniejszego poznania meandrów myśli biskupa Hippony dotyczącej odkupienia człowieka.

\section{MOŻLIWOŚĆ ZBAWIENIA POZA KOŚCIOŁEM}

Do struktury totus Christus należą wszyscy, którzy pozostają złączeni zarówno z Głową, jak i z Jej ciałem. Augustyn wielokrotnie podkreśla fakt, że chrześcijanie, pozostając związani z Chrystusem poprzez chrzest święty, zachowują również jedność pomiędzy sobą dzięki łączącym ich więzom, do których należą m.in. wspólna wiara i sakramenty, modlitwa zanoszona do jednego Ojca w niebie, wspólnie wypowiadane „amen”, jedna Ewangelia, jedna Pascha odprawiana ku czci Chrystusa ${ }^{72}$. Niemniej jednak te więzy nie zawsze wystarczają do tego, aby zachować rzeczywistą jedność pomiędzy członkami Kościoła. Szczególnie jest to widoczne w kontekście występowania takich zjawisk jak herezje i schizmy oraz w fenomenie istnienia złych chrześcijan. Wydaje się zatem, że przyjrzenie się sposobowi ich obecności w Kościele i relacji do niego, pozwoli w nowej perspektywie spojrzeć również na zagadnienie zbawienia człowieka, ponieważ odsłoni kolejne więzy łączące go z Kościołem i ukaże sens tego, co znaczy być poza Kościołem.

1. Przynależność do Kościoła - polemika antyheretycka. Herezja ${ }^{73}$ nie jest dla św. Augustyna czymś, co przychodzi do Kościoła z zewnątrz - od Ży-

${ }^{72}$ Por. tenże, De baptismo I 10, 14, NBA 15/1, 288, ŹMT 38, 44; tenże, Enarrationes in Ps. 54, 16, CCL 39, 668, PSP 38, 338; 32(3), 29, CCL 38, 272, PSP 37, 321. Zob. D. Drążek, Wokót wezwania , alleluja” w ,Enarrationes in Psalmos" św. Augustyna. Przyktady augustyńskiej katechezy o chwaleniu Boga, SPelp 26 (1997) 155-165; C. Mayer, Taufe und Erwärhlung. Zur Dialektik des sakramentum Begriffes in der antidonatischen Schrift Augustins: De baptismo, Würzburg 1975, 26.

${ }^{73}$ Mówiąc o heretykach, św. Augustyn rozumie pod tym terminem nie tylko tych, którzy głoszą błędne nauki, sprzeczne z doktryną Kościoła np. arian, ale także wszelkiego rodzaju schizmatyków, wśród których szczególną uwagę poświęca donatystom, ponieważ ich działalność w Afryce Prokonsularnej była problemem, z jakim zmagał się jako biskup Hippony. Dlatego heretyków i schizmatyków stawia na jednym poziomie, a terminy: „heretyk” i „schizmatyk”, często traktuje jako synonimy, mówiące o tym samym zjawisku. Tym, co łączy heretyków i schizmatyków jest bowiem odejście od prawdy, która znajduje się w Kościele. Poza tym Hippończyk zauważa, że herezja, odchodząc od nauki Kościoła, zawiera w sobie schizmę lub do niej prowadzi, co sprawia, iż heretycy dystansują się od tzw. Wielkiego Kościoła. Podobnie schizma, która ma u swoich korzeni jakiś sprzeciw wobec Kościoła i jego nauczania (np. schizma donatystów, spór o ważność chrztu udzielanego przez heretyków, czy spór o pokutę chrześcijan upadłych, w ostateczności były sporami o świętość Kościoła). Por. Augustinus, Enarrationes in Ps. 139, 5, CCL 40, 2015, PSP 42, 201; 67, 39, CCL 39, 896-897, PSP 39, 186-187; 54, 23, CCL 39, 673-674, PSP 38, 343. Z tego powodu termin „herezja”, „heretycy” stosowany będzie dalej na oznaczenie nie tylko samej błędnej doktryny i jej wyznawców, lecz także będzie on obejmował wszelkiego rodzaju schizmy oraz ich członków. Zob. M. Fiedrowicz, Theologie der Kirchenväter. Grundlagen frühchristlicher Gtaubensreflexion, 
dów lub pogan, lecz rozgrywa się w jego wnętrzu ${ }^{74}$. Heretykami mogą stać się więc wyłącznie chrześcijanie. Ponieważ zwracają się przeciwko Kościołowi i należą tym samym do grona jego prześladowców, to muszą oni w pewien sposób jednocześnie być także na zewnątrz niego ${ }^{75}$. Ta szczególna postawa, jaką zajmują heretycy wobec Kościoła, sprawia, że biskup Hippony nazywa ich jego ukrytymi nieprzyjaciółmi ${ }^{76}$.

Herezja zawsze ma swój początek - zdaniem św. Augustyna - w niezrozumieniu słowa Bożego, spowodowanym niejednokrotnie niejasnością tekstu biblijnego ${ }^{77}$. Nie jest to jednak warunek wystarczający, gdyż do zaistnienia herezji konieczne jest jeszcze odrzucenie autorytetu Kościoła wyjaśniającego Objawienie Boże ${ }^{78}$. W konsekwencji heretycy, decydując się na własną interpretację Pisma Świętego oraz na głoszenie nauki niezgodnej z doktryną Kościoła, faktycznie zrywają łączność z jego tradycją, a tym samym zamykają się na głos Ducha Świętego, który w niej rozbrzmiewa ${ }^{79}$.

Św. Augustyn, szukając źródła, z którego bierze początek herezja, wskazuje jednoznacznie na pychę ${ }^{80}$. Ci więc, którzy wprost sprzeciwiają się doktrynie Kościoła, nie głoszą nauki Bożej, ale własną chwałę (gloriam suam) ${ }^{81}$. Nie poszukują oni bowiem - zdaniem biskupa Hippony - kolejnych wyznawców Chrystusa, lecz jedynie skupiają wokół siebie własnych zwolenników, dla których stają się ślepymi wodzami, oczekującymi od swych słuchaczy dostrzeżenia i docenienia ${ }^{82}$.

Pycha odłącza heretyków od Kościoła, a tym samym odrywa ich od Chrystusa $^{83}$. Z tej racji stronnictwo tworzone jedynie przez nielicznych zwolenni-

Freiburg - Basel - Wien 2007, 370-371; W. Myszor, Herezja, w: Katolicyzm A-Z, red. Z. Pawlak, Poznań 1999, 131-134; D. Olszewski, Schizmy, w: Słownik Teologiczny, red. A. Zuberbier, Katowice 1998, 523-525; W. Łydka, Herezje, w: Stownik teologiczny, s. 193-195; Augustinus. Das Antlitz der Kirche, hrsg. H. Urs von Balthasar, Einsiedeln 1942, 310-322.

${ }^{74}$ Por. Augustinus, Enarrationes in Ps. 30(3), 8, CCL 38, 208, PSP 37, 254-255; 118(26), 4 , CCL 40, 1754, PSP 41, 319.

${ }^{75}$ Por. tamże 30(3), 8, CCL 38, 208, PSP 37, 254-255; 65, 5, CCL 39, 843, PSP 39, 126; 30(3), 9, CCL 38, 209, PSP 37, 256; 106, 14, CCL 40, 1580-1581, PSP 41, 120-121.

${ }^{76}$ Por. tamże 139, 5, CCL 40, 2015, PSP 42, 201; 60, 5, CCL 39, 768, PSP 39, 44.

${ }^{77}$ Por. tamże 54, 23, CCL 39, 673-674, PSP 38, 343.

${ }^{78}$ Por. tamże 147, 16, CCL 40, 2151, PSP 42, 353.

${ }^{79}$ Por. tamże 18(2), 5, CCL 38, 108-109, PSP 37, 153; 147, 16, CCL 40, 2151, PSP 42, 352-353. Zob. Pelikan, Powstanie wspólnej tradycji, s. 313-314.

${ }^{80}$ Por. Augustinus, Enarrationes in Ps. 130, 9, CCL 40, 1095, PSP 42, 80; 138, 26, CCL 40, 2008-2009, PSP 42, 192-193; 130, 11, CCL 40, 1907, PSP 42, 82.

${ }^{81}$ Por. tamże 95, 3, CCL 39, 1344, PSP 40, 269-270; 121, 13, CCL 40, 1813, PSP 41, 384. Zob. F. Ribbeck, Donatus und Augustinus oder der erste entscheidende Kampf zwischen Separatismus und Kirche, Elberfeld 1858, 112-121.

${ }^{82}$ Por. Augustinus, Enarrationes in Ps. 69, 5, CCL 39, 935, PSP 39, 229; 75, 7, CCL 39, 1041, PSP 39, 345.

${ }^{83}$ Por. tamże 68(2), 6, CCL 39, 922, PSP 39, 214-215; 54, 21, CCL 39, 672, PSP 38, 341-342; tenże, De Trinitate II 17, 30, NBA 4,116-118. 
ków ze swej natury nie może mieć charakteru wspólnoty powszechnej, obejmującej wszystkie narody i rozprzestrzenionej po całej ziemi - co ma miejsce w Kościele katolickim - lecz musi być jedynie zjawiskiem miejscowym i cząstkowym ${ }^{84}$.

Można zatem zauważyć, że jak zerwanie jedności z Bogiem powoduje odłączenie się od Kościoła ${ }^{85}$, tak też rozrywanie jedności we wspólnocie, którą stanowi Kościół, jest w zasadzie jej profanacją, a tym samym oderwaniem się od Boga, który ją zamieszkuje. Jedność pomiędzy członkami ciała Chrystusa jest bowiem zapośredniczona przez Głowę, a odłączenie się od Kościoła jest jednocześnie zerwaniem więzi miłości z samym Chrystusem, gdyż nie może On być Głową dla tego, kto nie zalicza się do członków Jego ciała ${ }^{86}$.

Należy więc uznać, że przynależność do stronnictwa heretyków powoduje odłączenie od życia Bożego (alienare a vita Dei), a poprzez to deprawuje (corrumpere), prowadząc ich do duchowej śmierci ${ }^{87}$. Skutkiem tego heretyk, znajdując się poza Kościołem i w odwróceniu od Boga, staje się uczestnikiem bezbożności (impietas) ${ }^{88}$. Chociaż więc wielu spośród nich słucha tego samego słowa Bożego oraz uznaje i sprawuje te same sakramenty, jakie są w Kościele, to jednak pozostają oni oddzieleni od niego ze względu na ową bezbożną pychę oraz nie mają udziału w łasce, która - jak stwierdza biskup Hippony jest mocą wszystkich sakramentów ${ }^{89}$. Św. Augustyn, odnosząc się w związku $\mathrm{z}$ tym do heretyków wprowadzających podziały wśród chrześcijan, naucza:

„Jest bowiem namiot Pański, sam Kościół święty, rozprzestrzeniony po całym świecie. Heretycy odchodzący od namiotów Kościoła, postawili sobie sami namioty. W tych namiotach męża nie będzie się dobrze czuł Bóg”"90.

Dlatego też, zauważając tę konsekwencję braku jedności, naucza wprost:

${ }^{84}$ Por. tenże, Enarrationes in Ps. 30(3), 8, CCL 38, 208, PSP 37, 254-255; 106, 14, CCL 40, 1580-1581, PSP 41, 120-121; tenże, De baptismo I 6, 8, NBA 15/1, 280, ŹMT 38, 39; Carney, The Doctrine of St. Augustine on Sanctity, s. 17-19; Mayer, Taufe und Erwärhlung, s. 24.

${ }^{85}$ Por. Augustinus, Enarrationes in Ps. 106, 14, CCL 40, 1580-1582, PSP 41, 119-122; 75, 8, CCL 39, 1042-1043, PSP 39, 346-347.

${ }^{86}$ Por. tamże 147, 18, CCL 40, 2154, PSP 42, 356-358; 36(3), 19, CCL 38, 381, PSP 38, 38-39. Zob. G.G. Willis, St. Augustine and the Donatist Controversy, London 1950, 113-117.

${ }^{87}$ Por. Augustinus, Enarrationes in Ps. 106, 14, CCL 40, 1580-1582, PSP 41, 119-122; 75, 8, CCL 39, 1042-1043, PSP 39, 346-347; 138, 26, CCL 40, 2006-2007, PSP 42, 192-193; 18(2), 6, CCL 38, 109-110, PSP 37, 153-154.

${ }^{88}$ Por. tamże 31(2), 18, CCL 38, 138, PSP 37, 286.

${ }^{89}$ Por. tamże 77, 2, CCL 39, 1067: ,[...] cum essent omnia communia sacramenta, non communis erat omnibus gratia, quae sacramentorum virtus est. Sicut et nunc iam revelata fide quae tunc velabatur, omnibus in nomine Patris, et Filii, et Spiritus sancti baptizatis, commune est lavacrum regenerationis; sed ipsa gratia cuius ipsa sunt Sacramenta, qua membra corporis Christi cum suo capite regenerata sunt, non communis est omnibus", PSP 39, 372-373.

${ }^{90}$ Tamże 146, 19, CCL 40, 2137: „Est enim tabernaculum Domini, ipsa sancta Ecclesia toto orbe diffusa. Haeretici dividentes se ab Ecclesiae tabernaculis, sibi tabernacula posuerunt: non in ipsis tabernaculis viri bene sentiet Deus", PSP 42, 336-337. 
„Poza swoim domem Bóg nie wysłuchuje na żywot wieczny”91.

Zatem ci, którzy wychodzą poza Kościół, nie są już oświecani światłem Bożym, lecz takim, które czerpią jedynie z siebie ${ }^{92}$. Nie uczestniczą więc również w więzach nauki Bożej.

Pycha separacji, skupiając heretyków na sobie samych, a przez to odrywając od innych, polega więc przede wszystkim - co podkreśla św. Augustyn - na braku jednej miłości (una caritas) ${ }^{93}$. Chociaż byli oni niegdyś w Kościele, to jednak obecnie nie są z nim jednego ducha. $Z$ tego powodu, mimo, iż posiadają sakrament chrztu, spotka ich Boży gniew i kara polegająca na wiecznym potępieniu ${ }^{94}$. W tym przypadku najbardziej spełnia się całkowicie zasada, która mówi, że poza Kościołem nie ma zbawienia.

Skoro brak wspólnej miłości i jednego ducha powoduje wyłączenie ze wspólnoty Kościoła oraz oddzielenie od łaski Bożej, to rozdzielenie to musi posiadać też charakter duchowy i dotyczy nie tylko heretyków, którzy w sposób widzialny odłączyli się od Kościoła, lecz także tych, którzy wydają się pozostawać jego członkami, lecz jednak odłączyli się od niego w sposób duchowy.

2. Fałszywi chrześcijanie. Św. Augustyn, charakteryzując tych, których nazywa złymi chrześcijanami (mali christiani) ${ }^{95}$, fałszywymi braćmi (falsi fratres $)^{96}$ lub też pseudochrześcijanami (pseudochristiani) ${ }^{97}$, stwierdza:

„[...] najpierw przyznają się do wiary, zostają oczyszczeni słowem Bożym i egzorcyzmem w imię Chrystusa, otrzymują łaskę Bożą, przyjmują chrzest, a później wracają do gorszego zła, niż je przedtem popełniali" ${ }^{98}$.

${ }^{91}$ Tamże 131, 13, CCL 40, 1917: „Praeterquam domum suam, non exaudit Deus ad vitam aeternam", PSP 42, 93. Por. tenże, Contra Faustum Manichaeum 12, 16-17, NBA 14/1, 144-146, PSP 55, 77. Jest to więc powtórzenie tezy św. Cypriana (Epistula 73, 21, 2, CCL 3C, 555): „Salus extra Ecclesiam non est”. Por. H. von Campenhausen, Ojcowie Kościoła, tłum. K. Wierszyłowski, Warszawa 1967, 385-388; S. Kowalczyk, Człowiek i Bóg w nauce św. Augustyna, Lublin 2007, 192195; Urs von Balthasar, Sponsa Verbi, s. 225-227.

${ }_{92}$ Por. Augustinus, Enarrationes in Ps. 75, 8, CCL 39, 1042, PSP 39, 346-347.

${ }^{93}$ Por. tamże 54, 19, CCL 39, 671, PSP 38, 340. Brak jednej miłości oznacza nie tylko podział zachodzący pomiędzy członkami Kościoła, ale przede wszystkim brak uczestnictwa w miłości udzielanej przez Trójcę Świętą i ofiarowanej przez zesłanie Ducha Świętego. Podkreślając ten fakt, A. de Maria (Credo nello Spirito Santo la santa Chiesa. La pneumatologia agostiniana e i suoi influssi sulla eccesiologia dell'Ipponate, Roma 2009, 49) zauważa, że herezja donatyzmu (a należałoby dodać, że również każda herezja), łamiąc jedność Kościoła, jest w swej istocie herezją pneumatologiczną.

${ }^{94}$ Por. Augustinus, Enarrationes in Ps. 54, 20, CCL 39, 671-672, PSP 38, 341.

${ }^{95}$ Por. tamże 85, 19, CCL 39, 1192, PSP 40, 104.

${ }^{96}$ Por. tenże, De fide et operibus 2, 3, ed. G. Ceriotti - L. Alici - A. Pieretti - F. Monteverde, NBA 6/2, Roma 1995, 696, thum. W. Budzik: Św. Augustyn, Wiara i uczynki, w: Św. Augustyn, Pisma katechetyczne, s. 173.

${ }^{97}$ Por. tenże, De baptismo I 16, 25, NBA 15/1, 302-304, ŹMT 38, 52-53; III 19, 26, NBA 15/1, 374-378, ŹMT 38, 93.

${ }^{98}$ Tenże, Enarrationes in Ps. 48(2), 1, CCL 38, 565: ,[...] primo accedunt ad fidem mundati 
To powtórne zwrócenie się w stronę zła, warunkujące ich przynależność do świata, wyznacza jednocześnie specyficzną relację tego rodzaju chrześcijan do Kościoła. Sakramenty, które przyjmują, a szczególnie chrzest, ta sama Modlitwa Pańska, którą odmawiają wraz z całym Kościołem oraz przystępowanie do tego samego ołtarza, sprawiają, iż przynależą oni do ciała Chrystusa i mogą nazywać się chrześcijanami. Równocześnie jednak, ze względu na brak dobrych obyczajów i pobożności, stają się wobec niego obcymi w takim stopniu, że Hippończyk określa wręcz nieporozumieniem to, iż nazywa się ich jeszcze chrześcijanami ${ }^{99}$. To wewnętrzne napięcie bliskości i alienacji, istniejące pomiędzy przynależnością do wspólnoty wierzących w Chrystusa a oddzieleniem od niej, św. Augustyn oddaje za pomocą pojęcia zamieszkiwania (incolatio) i charakteryzuje je następująco:

„Albowiem wchodzi [zły chrześcijanin] jak swój i nie unika się go jako obcego. [...] W ten sposób bowiem wchodzi do dużego domu nie trwając w nim. Dlatego «zamieszkują». [...] Kto wchodzi jako syn ten nie zamieszkuje, lecz przebywa do końca"100.

Oni zatem nie trwają w Kościele, lecz jedynie zamieszkują go, są w Kościele i równocześnie poza nim.

Zamieszkujący w Kościele źli chrześcijanie, poszukują przede wszystkim szczęścia ziemskiego (felicitas terrena), ale ze względu na fundament wiary mogą go szukać u Boga, a niekoniecznie przeciwko Niemu ${ }^{101}$. Chociaż więc fundament wiary ukierunkowuje w pewien sposób cielesne dążenia chrześcijan światowych, to jednak nie zmienia ich podstawowego charakteru, jakim jest grzeszne pożądanie dóbr doczesnych ${ }^{102}$.

Przez to wyobcowują się oni z Kościoła, nie chcą żyć życiem prawdziwych chrześcijan, lecz postępują według swoich własnych obyczajów (secundum

verbo Dei et exorcismis in nomine Christi, ut accipiant gratiam Dei, ut baptizentur, et postea redeuntes ad peiora mala quam antea commiserant", PSP 38, 234.

${ }^{99}$ Por. tamże 47, 8, CCL 38, 545, PSP 38, 213-214; 30(4), 3, CCL 38, 214, PSP 37, 260; Clemens Alexandrinus, Stromata VII 87, 3 - 88, 4, ed. L. Früchtel, GCS 17², Berlin 1970, 62-63.

${ }^{100}$ Augustinus, Enarrationes in Ps. 55, 9, CCL 39, 684: „Intrat etenim tamquam tuus, non cavetur ut alienus. [...] Quia sic intrant in domum magnam, non ibi perseveraturi; ideo «incolent». [...] Qui intrat ut filius, non incolet, quia perseverabit usque in finem", PSP 38, 354. Por. Drączkowski, Poza Kościołem nie ma zbawienia, s. 130-131.

${ }^{101}$ Por. Augustinus, Enarrationes in Ps. 119, 7, CCL 40, 1784, PSP 41, 353; tenże, De civitate Dei XV 7, CCL 48, 459-462, tłum. Kubicki, s. 556-557. Dlatego środowisko chrześcijan światowych jest bardzo zróżnicowane: rozciąga się od tych, którzy będąc w Kościele, żyją w nieprawościach i nie chcą się poprawić, aż do takich, którzy kierując się miłością światową, stawiają jednak Chrystusa na pierwszym miejscu.

102 Por. tenże, Contra Faustum Manichaeum 22, 27-28, NBA 14/2, 508-510, PSP 56, 26 27; tenże, De catechizandis rudibus 7, 11, ed. I.B. Bauer, CCL 46, Turnholti 1969, 131-132, tłum. W. Budzik: Św. Augustyn, Początkowe nauczanie religii, w: Św. Augustyn, Pisma katechetyczne, s. 33. 
modum suum $)^{103}$. Poszukując swego szczęścia oraz poruszając się wewnątrz logiki świata, co w praktyce oznacza odrzucenie woli Bożej i postawienie na jej miejscu własnej pychy ${ }^{104}$, pogrążają się coraz bardziej w grzechu ${ }^{105}$. Jego podstawą zaś jest bezbożność, polegająca na nieobecności Boga w ich myśleniu i na stawianiu siebie ponad Niego ${ }^{106}$.

Kierowanie się wartościami doczesnymi przez chrześcijan skutkuje zatem nieobecnością Boga $\mathrm{w}$ ich sercach oraz prowadzi ich na drogę wiodącą poza Kościół. Przybiera ona formę moralności, poruszającej się wokół innego centrum, jakim jest własna korzyść, wynikająca z logiki pychy. Charakteryzując ową drogę, biskup Hippony stwierdza:

„Albowiem wielu złych chrześcijan wpatrujących się w codzienność, a także poszukujących i obserwujących czasy i dni, gdy są upominani przez nas [...] dlaczego tak czynią, odpowiadają: «To jest konieczne ze względu na doczesność; chrześcijanami zaś jesteśmy ze względu na życie wieczne» [...]. Wynika z tego, aby krócej powiedzieć, że ze względu na życie wieczne Bóg jest czczony, a ze względu na życie doczesne - diabel"107.

Skoro znają oni drogę sprawiedliwości, a mimo to nie chcą się nawrócić ze swego złego życia, to podobni są - jak twierdzi biskup Hippony - do bezużytecznych latorośli, odciętych od winnego krzewu, które nie nadają się już do żadnej innej obróbki, jak tylko na spalenie ${ }^{108}$. Ogień sądu oznacza dla nich potępienie, wykluczające z królestwa Bożego ${ }^{109}$.

Można łatwo zauważyć, że podobnie jak w przypadku heretyków, tym, co wyrzuca ich poza Kościół, jest pycha, gdyż bardziej szukają oni własnej korzyści niż Boga. Skoro jednak niweczy ona moc sakramentów, tak, iż nie mogą

${ }^{103}$ Por. tenże, Enarrationes in Ps. 103(3), 5, CCL 40, 1504, PSP 41, 37; 30(4), 3, CCL 38, 213 214, PSP 37, 260.

${ }^{104}$ Por. tenże, Contra Faustum Manichaeum 32, 18, NBA 14/2, 720-722, PSP 56, 139; tenże, Enarrationes in Ps. 90(1), 9, CCL 39, 1262, PSP 40, 182.

${ }^{105}$ Por. tenże, De catechizandis rudibus 7, 11, CCL 46, 132, thum. Budzik, s. 13; tenże, Enarrationes in Ps. 130, 2, CCL 40, 1899, PSP 42, 72-73.

${ }^{106}$ Por. tenże, Contra Faustum Manichaeum 22, 78, NBA 14/2, 582, PSP 56, 67; tenże, Enarrationes in Ps. 32(2), 1, CCL 38, 247, PSP 37, 295.

${ }^{107}$ Tenże, Enarrationes in PS. 40, 3, CCL 38, 450-451: „Multi enim mali christiani, inspectores ephemeridarum et inquisitores atque observatores temporum te dierum, cum coeperint ibi obiurgari a nobis $[\ldots]$ quare ista faciant, respondent: Haec propter tempus hoc necessaria sunt; christiani autem sumus propter vitam aeternam [...]. Relinquitur, ut hoc breviter dicant, ut propter vitam aeternam Deus et propter vitam praesentiam diabolus colatur", tłum. własne. Por. tenże, De baptismo I 15, 24, NBA 15/1, 302, ŹMT 38, 52.

${ }^{108}$ Por. tenże, Enarrationes in Ps. 30(3), 6, CCL 38, 206, PSP 37, 252-253.

${ }^{109}$ Por. tenże, De baptismo IV 18, 25, NBA 15/1, 424, ŹMT 38, 123; tenże, Enarrationes in Ps. 88(2), 4, CCL 39, 1235, PSP 40, 152; tenże, Contra Secundinum 8, ed. G. Sfameni Gasparro A. Cosentino - C. Magazzù - F. Monteverde, NBA 13/2, Roma 2000, 566-568, tłum. J. Sulowski: Św. Augustyn, Przeciw Sekundynowi, w: Św. Augustyn, Przeciw Faustusowi (Księgi XXII-XXXIII), Przeciw Sekundynowi, PSP 56, 169. 
one wydać w człowieku właściwych im owoców, to należy uznać, że granica Kościoła nie jest wyznaczona jedynie poprzez czysto formalne uczestnictwo w wierze i kulcie chrześcijańskim, lecz posiada ona charakter rzeczywistości aksjologicznej, rozgrywającej się pomiędzy dobrem a złem. Czynnikiem decydującym o przynależności do Kościoła i o łączności człowieka z Bogiem jest zatem, obok łaski Bożej, dobra wola skierowana ku rzeczywistości Boskiej i duchowej ${ }^{110}$. Wolę ukierunkowaną na jakieś dobro nazywa św. Augustyn miłością (caritas, dilectio) ${ }^{111}$ i to właśnie ona jest siłą, która decyduje o przynależności do Kościoła, otwierając ludzkie serce na przyjęcie Bożej łaski.

Miłość kieruje jednych w stronę Boga, pobudzając w nich pragnienie zjednoczenia się z Nim, zaś innych prowadzi ku pragnieniu posiadania wartości doczesnych i szczęścia ziemskiego ${ }^{112}$. Św. Augustyn podkreśla również, że wszelkie dary, jakich Bóg udziela człowiekowi, zarówno te widzialne, doczesne, jak i duchowe, mają swe źródło w miłości, a bez niej byłyby niczym (por. 1Kor 13, 1-13) ${ }^{113}$. Dopiero wówczas możliwe jest uświęcenie wyznawców Chrystusa, gdy towarzyszy im podstawowy i największy dar udzielany przez Boga, którym jest - zdaniem biskupa Hippony - miłość (caritas) ${ }^{114}$. Ona zatem wyznacza najdoskonalszą drogę, na której Bóg uświęca swój Kościół i jego członków ${ }^{115}$, a także wypełnia całą przestrzeń istnienia Kościoła, stanowiąc niejako - jak można wnioskować - o jego tożsamości. Każdy bowiem, kto znajduje się poza tą miłością, która jest udziałem Kościoła, nie może do niego należeć116.

Granica Kościoła posiada więc charakter duchowy ${ }^{117}$. Dlatego też biskup Hippony, porównując Kościół do arki Noego, w której ludzie sprawiedliwi znaleźli ocalenie, stwierdza:

${ }^{110}$ Por. tenże, Enarrationes in Ps. 9, 17, CCL 38, 67, PSP 37, 111; 8, 1, CCL 38, 49, PSP 37, 92. Zob. van Bavel, Chiesa, s. 367; Cipriani, Molti e uno solo in Christo, s. 232-239.

${ }^{111}$ Por. Augustinus, De Trinitate VIII 10, 14, NBA 4, 358, POK 25, 276; T.J. van Bavel, Amore, w: Agostino. Dizionario Enciclopedico, s. 175-179 i 184-186.

${ }_{112}$ Por. Augustinus, De Trinitate VIII 7, 10, NBA 4, 350, POK 25, 271; VIII 10, 14, NBA 4, 358, POK 25, 276.

${ }^{113}$ Por. tenże, De baptismo III 16, 21, NBA 15/1, 368-370, ŹMT 38, 89.

${ }_{114}$ Por. tenże, Enarrationes in PS. 146, 10, CCL 40, 2128-2129, PSP 42, 327-328; 77, 10, CCL 39, 1075, PSP 39, 381-382; 96, 20, CCL 39, 1371, PSP 40, 297; 130, 8, CCL 40, 1904, PSP 42, 79. Zob. D. Dideberg, Dilectio, w: Augustinus-Lexikon, hrsg. C. Mayer et al., II/3-4, Basel - Stuttgart 1999, 443-444; L. Nieścior, Myśl wczesnochrześcijańska wobec wyzwania czasu. Wybrane zagadnienia z teologii ojców, Poznań 2002, 224; P. Borgomeo, L'Église de ce temps dans la predication de saint Augustin, Paris 1972, 246-250; A. Piela, Mysterium Christi totius ut fundamentum unitatis Ecclesiae apud S. Augustinum, Roma 1964, 55.

${ }^{115}$ Por. Augustinus, Enarrationes in Ps. 146, 10, CCL 40, 2128-2129, PSP 42, 327-328; 103(1), 9, CCL 40, 1481-1482, PSP 41, 12-13.

${ }_{116}$ Por. tenże, De Trinitate XV 18, 32, NBA 4, 680, POK 25, 439; tenże, Enarrationes in Ps. 130, 8, CCL 40, 1904, PSP 42, 79.

${ }^{117}$ Por. tenże, De baptismo VI 5, 7, NBA 15/1, 498-500, ŹMT 38, 167; van Bavel, Chiesa, s. 368. 
„Z całą pewnością jest sprawą oczywistą, że wyrażenie «wewnątrz Kościoła» lub «poza nim» należy odnosić do serca, a nie do ciała. Ponieważ wszyscy znajdujący się sercem wewnątrz w jedności arki zostają ocaleni «przez tę samą wodę», przez którą wszyscy znajdujący się sercem poza Kościołem, niezależnie, czy ciałem są wewnątrz, czy na zewnątrz, umierają jako wrogowie jedności. [...] Tak i nie inaczej, ale przez ten sam chrzest dobrzy katolicy zostają zbawieni, a źli katolicy lub heretycy są zgubieni"'118.

Przynależność do Kościoła „sercem” a nie „ciałem” oznacza więc, że nie każdy chrześcijanin jest rzeczywistym członkiem struktury totus Christus, jak również, że nie przed każdym, kto nie przyjął chrztu, zamknięta zostaje możliwość zbawienia. Granice wspólnoty zbawionych lub podążających drogą do zbawienia przebiegają bowiem w poprzek przynależności instytucjonalnej i czysto zewnętrznej. Myśl ta znajduje swój wyraz przede wszystkim w idei państwa Bożego (civitas Dei).

3. Obywatele państwa Bożego. Państwo Boże jest rzeczywistością o charakterze duchowym, znacznie wykraczającą poza ramy instytucjonalnego Kościoła ${ }^{119}$. Jest ono rozumiane przez św. Augustyna przede wszystkim jako społeczność świętych założona przez Boga już w akcie stwórczym ${ }^{120}$. Dlatego - jak podkreśla Hippończyk - integralną, a nawet najświetniejszą częścią tej wspólnoty, są aniołowie, którzy uczestnicząc w niezmiennym, boskim świetle, tj. w Słowie Bożym, sami stają się światłością, choć zawsze jako partycypujący w Bogu ${ }^{121}$. Sam Bóg jest źródłem ich szczęśliwości, radości oraz siły ${ }^{122}$, gdyż zostali stworzeni po to, by mogli na wieki cieszyć się niezmiennym i najwyższym Dobrem ${ }^{123}$.

W społeczności tej nastąpił jednak głęboki podział, którego konsekwencje wykraczają znacznie poza jej ramy. Niektóre bowiem spośród tych duchów odwróciły się od Bożego oświecenia, a nie posiadając w sobie samych światła, stały się ciemnością oraz duchami nieczystymi (immundi) ${ }^{124} \mathrm{i}$ bezbożnymi

${ }^{118}$ Augustinus, De baptismo V 28, 39, NBA 15/1, 490: „Certe manifestum est, id quod dicitur, in Ecclesia intus et foris, in corde, non in corpore cogitandum; quandoquidem omnes qui corde sunt intus, in arcae unitate per eamdem aquam salvi fiunt, per quam omnes qui corde sunt foris, sive etiam corpore foris sint, sive non sint, tamquam unitatis adversarii moriuntur. [...] sic non alio, sed eodem Baptismo et boni catholici salvi fiunt, et mali catholici vel haeretici pereunt", ŹMT 38, 162. Por. tenże, Contra Faustum Manichaeum 12, 16, NBA 14/1, 144, PSP 55, 77.

${ }_{119}$ Por. Sz. Pieszczoch, Chrześcijańska wizja dziejów człowieka i świata u św. Augustyna, AK 71 (1979) t. 93, 74; Cz. Bartnik, Augustyńska historiologia, VoxP 8 (1988) t. 15, 792; B. Forte, La Chiesa della Trinità. Saggio sul mistero della Chiesa, comunione e missione, Milano 2003, s. 81-83.

${ }^{120}$ Por. J. Salij, Wstęp (Prezentacja dzieła), w: Święty Augustyn, Państwo Boże, s. 8.

${ }^{121}$ Por. Augustinus, De civitate Dei XI 9, CCL 48, 329-330, thum. Kubicki, s. 412-413.

${ }^{122}$ Por. tamże XI 24, CCL 48, 344, tłum. Kubicki, s. 429.

${ }^{123}$ Por. tamże XI 13, CCL 48, 333-334, thum. Kubicki, s. 417.

${ }^{124}$ Por. tamże XI 9, CCL 38, 330, thum. Kubicki, s. 413. 
(impii $)^{125}$. W ten sposób zaistniały dwie społeczności, dwa państwa, które biskup Hippony charakteryzuje w następujących słowach:

„[...] jedno, co się Bogiem cieszy, drugie, co się pychą nadyma; [...] jedno, pałające świętą miłością Boga, drugie - dymiące nieczystą miłością własnego wyniesienia się"126.

Należy zauważyć, że różnica pomiędzy tymi społecznościami nie zachodzi na płaszczyźnie ontycznej, gdyż wszyscy aniołowie posiadają taką samą naturę, lecz rozgrywa się ona przede wszystkim na poziomie aksjologicznym, ponieważ polega na zwróceniu wolnej woli w przeciwnych kierunkach i na pragnieniu posiadania różnych dóbr. Autor De civitate Dei w ten sposób o tym naucza:

„Jedni wytrwale pozostali w ogólnym dla wszystkich dobru, którym dla nich jest sam Bóg - w Jego wieczności, prawdzie i miłości. Inni, rozmiłowani raczej we własnej swej mocy, jak gdyby dobro ich w nich samych było, od najwyższego i wszystkim wspólnego dobra odpadli, ku sobie zwróceni; a wielbiąc dziką pychę swoją, zamiast wiekuistej chwały, kłamstwo głupie, zamiast najpewniejszej prawdy, stronniczość, zamiast miłości niepodzielnej - stali się nadęci pychą, kłamliwi i zawistni. Źródłem szczęścia aniołów dobrych jest łączność z Bogiem, dlatego też za nieszczęście złych aniołów uważać trzeba to, co jest wprost przeciwne tamtemu źródłu, a więc nienależenie do Boga"127.

Jak zatem trwanie przy Bogu ma swe źródło w miłości ku Niemu, tak też odwrócenie się od Niego jest wyrazem miłości, która przenosi siebie ponad swego Stwórcę ${ }^{128}$. To oderwanie się od Boga, polegające na porzuceniu najwyższego Dobra, a zwróceniu się ku dobrom niższym i ku sobie, jest podstawowym złem, które św. Augustyn określa mianem pychy ${ }^{129}$. Polega ona na

${ }^{125}$ Por. tenże, Contra Faustum Manichaeum 20, 22, NBA 14/2, 432, PSP 55, 238.

${ }^{126}$ Tenże, De civitate Dei XI 33, CCL 48, 353: ,[...] unam fruentem Deo, alteram tumentem typho; [...] unam Dei sancto amore flagrantem, alteram propriae celsitudinis immundo amore fumantem", thum. Kubicki, s. 439.

${ }^{127}$ Tamże XII 1, 2 CCL 48, 355: ,[...] alii constanter in communi omnibus bono, quod ipse illis Deus est, atque in eius aeternitate veritate caritate persistunt; alii sua potestate potius delectati, velut bonum suum sibi ipsi essent, a superiore communi omnium beatifico bono ad propria defluxerunt et habentes elationis fastum pro excelsissima aeternitate, vanitatis astutiam pro certissima veritate, studia partium pro individua caritate superbi fallaces invidi effecti sunt. Beatitudinis igitur illorum causa est adhaerere Deo; quocirca istorum miseriae causa ex contrario est intellegenda, quod est non adhaerere Deo", thum. Kubicki, s. 442-443.

${ }^{128}$ Por. tenże, De doctrina christiana I 23, 22-23, ed. J. Martin, CCL 32, Turnholti 1962, 18-19, tłum. J. Sulowski: Św. Augustyn, O nauce chrześcijańskiej, Warszawa 1989, 29; tenże, De civitate Dei XII 5, CCL 48, 359, tłum. Kubicki, s. 447; tenże, Contra Secundinum 17-18, NBA 13/2 ,582586, PSP 56, 179-180.

${ }^{129}$ Por. tenże, De Trinitate VIII 3, 5, NBA 4, 334-336, POK 25, 262-263; tenże, De civitate Dei XII 6, CCL 48, 359, thum. Kubicki, s. 447; tenże, Enchiridion ad Laurentium 9, 28, CCL 46, 64-65, thum. Budzik, s. 99. 
pożądaniu przewrotnej wyniosłości, na zbytnim upodobaniu w sobie ${ }^{130}$, czyli na przewrotnej miłości (perversa amor) ${ }^{131}$, która prowadzi do ślepoty serca ${ }^{132}$, deprawuje wolę $\mathrm{i}$ jest przez to początkiem wszelkiego grzechu ${ }^{133}$.

Czynnikiem różnicującym byty anielskie jest zatem dobra i zła wola, czyli dwa rodzaje miłości. One są również elementem konstytuującym te rozbieżne względem siebie społeczności, które biskup Hippony nazywa, posługując się językiem biblijnym, Jerozolimą i Babilonem ${ }^{134}$. Przeciwstawienie tych miast wynika ze skierowania ich obywateli ku zupełnie odmiennym - choć przecież nie równoważnym sobie - celom. Św. Augustyn istotę tego skierowania wyjaśnia następująco:

„Owe dwa miasta powstają skutkiem dwojakiej miłości. Miłość Boga tworzy Jerozolimę, Babilon zaś miłość światowa"135.

Jerozolima jest więc społecznością świętych, szukających chwały Boga i złączonych z Nim jako swym najwyższym Dobrem, zaś Babilon to duchowa rzeczywistość skupiająca w sobie wszystkich, dla których dobrem jest miłość samego siebie i własna chwała ${ }^{136}$. Dlatego królem Jerozolimy jest sam Bóg ${ }^{137}$, natomiast władcą Babilonu pozostaje diabe ${ }^{138}$. Ten początkowy podział skutkuje więc powstaniem dwóch państw, których dzieje znajdują swój wyraz w historii zbawienia, będącej również częścią losów ludzkości.

W pierwszym człowieku - jak zauważa św. Augustyn - istniały oba te państwa $^{139}$. Dopiero z niego bowiem powstał rodzaj ludzki, podzielony pod względem duchowym na dwie społeczności: państwo Boże oraz państwo ziemskie. Pochód civitas Dei poprzez dzieje zapoczątkowuje więc biblijny Abel, natomiast miasto królestwa ziemskiego zakłada jego starszy brat - Kain ${ }^{140}$. Zasada

${ }^{130}$ Por. tenże, De civitate Dei XIV 13, CCL 48, 434, tłum. Kubicki, s. 528.

${ }^{131}$ Por. tamże XII 8, CCL 48, 362-363, tłum. Kubicki, s. 451.

${ }^{132}$ Por. tenże, Contra Faustum Manichaeum 16, 14, NBA 14/1, 288, PSP 55, 156.

${ }^{133}$ Por. tenże, De peccatorum meritis II 17, 27, NBA 17/1, 158; tenże, De civitate Dei XII 9 , CCL 48, 363-364, thum. Kubicki, s. 451-452; tenże, De Trinitate XII 9, 14 - 10, 15, NBA 4, 482-484, POK 25, 338-339.

${ }^{134}$ Por. tenże, De civitate Dei XV 1, CCL 48, 453-455, thum. Kubicki, s. 549; tenże, Enarrationes in Ps. 64, 2, CCL 39, 823, PSP 39, 104; tenże, De catechizandis rudibus 21, 37, CCL 46,161, thum. Budzik, s. 43.

135 Tenże, Enarrationes in Ps. 64, 2, CCL 39, 824: „Duas istas civitates faciunt duo amores: Ierusalem facit amor Dei; Babyloniam facit amor saeculi”, PSP 39, 105. Por. tenże, De civitate Dei XI 28, CCL 48, 347-349, thum. Kubicki, s. 433-434; XIV 7, CCL 48, 421-423, thum. Kubicki, s. 516.

${ }^{136}$ Por. tenże, De civitate Dei XIV 28, CCL 48, 451-452, thum. Kubicki, s. 546-547; tenże, De doctrina christiana I 33, 36, CCL 32, 26-27, thum. Sulowski, s. 41.

${ }^{137}$ Por. Tenże, Enarrationes in Ps. 61, 7, CCL 39, 778, PSP 39, 55.

${ }^{138}$ Por. tamże 61, 6, CCL 39, 777, PSP 39, 54. Zob. E. Lamirande, Babylon(ia), w: Augustinus-Lexikon, hrsg. C. Mayer et al., I/4, Basel - Stuttgart 1990, 566-569.

${ }^{139}$ Por. Augustinus, De civitate Dei XII 28, CCL 48, 384-385, thum. Kubicki, s. 474.

${ }^{140}$ Por. tamże XV 1, CCL 48, 453-454, tłum. Kubicki, s. 549; XV 5, CCL 48, 475, thum. Kubicki, s. 553; tenże, Enarrationes in Ps. 142, 3, CCL 40, 2061, PSP 42, 251. Zob. Y. Congar, Ecclesia 
funkcjonowania tych rzeczywistości we wspólnocie ludzkiej jest jednak taka sama jak w przypadku bytów anielskich, gdyż granicą podziału jest miłość. Mieszkańcy Jeruzalem, trwając całkowicie w Bogu, kierują się jedynym prawem, jakie obowiązuje w tym mieście, a mianowicie prawem miłości ${ }^{141}$. Można nawet stwierdzić, że Hippończyk uważa ją za konieczny warunek wejścia w mury niebieskiego miasta, gdyż dzięki niej wielu umiera dla świata, by żyć wyłącznie dla Boga ${ }^{142}$. Natomiast drugą społeczność Hippończyk charakteryzuje w następujących słowach:

„Wszyscy rozumujący po ziemsku, wszyscy, którzy ziemską szczęśliwość wyżej cenią niż Boga, wszyscy szukający swego, a nie tego, co Jezusa Chrystusa, przynależą do jednego miasta, które mistycznie nazywa się Babilonem, a którego królem jest diabeł"143.

Ze względu na tę miłość, czyli wybrane dobro, św. Augustyn zalicza do obywateli państwa Bożego wszystkich sprawiedliwych. Dlatego też stwierdza:

„Otóż wszyscy, którzy stanowią dom Boga, nie tylko ci, którzy obecnie żyją, lecz i ci, którzy przed nami byli i już śpią oraz ci, którzy po nas przyjdą, którzy jeszcze mają się narodzić porządkiem rzeczy ludzkich, aż do skończenia świata, zgromadzeni w jedno wierzący niezliczeni, przez Pana jednak policzeni [...]. Otóż ta cała liczba wiernych świętych, powstała z ludzi przemienionych do tego stopnia, że zrównali się z aniołami Bożymi, w połączeniu $\mathrm{z}$ aniołami [...], ci wszyscy razem stanowią jeden dom Boga i jedno miasto.

To właśnie jest Jerozolima"144.

ab Abel, w: Abhandlungen über Theologie und Kirche. Festschrift für Karl Adam, hrsg. M. Reding, Düsseldorf 1952, s. 79-108; van Bavel, Chiesa, s. 493-494; L.F. Pizzolato, Il libro XV del „, De Civitate Dei”, w: Lettura del „De Civitate Dei” Libri XI-XVI. Lectio Augustini XXI-XXII. Settimana Agostiniana Pavese (2005-2006), SEA 115, Roma 2009, 143-152.

${ }^{141}$ Por. Augustinus, Enarrationes in Ps. 98, 4, CCL 39, 1381, PSP 40, 307-308; 149, 5, CCL 40, 2182, PSP 42, 338. Zob. H. Arendt, Love and Saint Augustin, Chicago 1996, 111.

${ }^{142}$ Por. Augustinus, Enarrationes in PS. 47, 13, CCL 38, 548, PSP 38, 217.

${ }^{143}$ Tamże 61, 6, CCL 39, 777: „Omnes qui terrena sapiunt, omnes qui felicitatem terrenam Deo praeferunt, omnes qui sua quaerunt, non quae Iesu Christi, ad unam illam civitatem pertinent, quae dicitur Babylonia mystice, et habet regem diabolum", PSP 39, 54. Por. tenże, De catechizandis rudibus 19, 31, CCL 46, 155-156, thum. Budzik, s. 38.

${ }^{144}$ Tenże, Enarrationes in Ps. 126, 3, CCL 40, 1858: „Omnes autem fideles, quae est domus Dei, non solum qui modo sunt, sed et qui ante nos fuerunt et iam dormierunt, et qui post nos futuri sunt, adhuc qui nasci habent in rebus humanis usque in finem saeculi, congregati in unum fideles innumerabiles, sed Domino numerati [...]. Omnis ergo numerus fidelium sanctorum, ex hominibus commutandorum ut fiant aequales Angelis Dei, adiuncti etiam ipsi Angelis [...], omnes simul unam domum Dei faciunt, et unam civitatem. Ipsa est Ierusalem", PSP 42, 27-28. Por. tenże, De catechizandis rudibus 19, 33, CCL 46, 157-158, thum. Budzik, s. 39. 
Należą więc do niej już święci Starego Testamentu tacy jak: Set ${ }^{145}$, Henoch $^{146}, \mathrm{Noe}^{147}, \mathrm{Sem}^{148}$, Abraham, Izaak ${ }^{149}$, Jakub ${ }^{150}$, Mojżesz i Jozue ${ }^{151}$, Samuel i Dawid ${ }^{152}$ oraz prorocy ${ }^{153}$, Daniel, młodzieńcy ocaleni przez Boga z pieca ognistego, czy też bohaterscy Machabeusze ${ }^{154}$. Nie są oni uczestnikami sakramentu chrztu, lecz należą do rzeczywistości określanej przez św. Augustyna mianem duchowego, tzn. prawdziwego Izraela ${ }^{155}$. W związku z tym naucza on:

„Są więc Żydzi obrzezani cieleśnie i są Żydzi obrzezani w sercu. Wielu naszych świętych ojców posiadało zarówno obrzezanie ciała jako znamię wiary, jak obrzezanie serca ze względu na samą wiarę. Od nich odszczepili się ci, którzy obecnie chlubią się imieniem, a zgubili uczynki. Otóż od tych ojców sprzeniewierzyli się Żydzi, pozostali Żydami w ciele, a w sercu stali się poganami" ${ }^{156}$.

Należy więc uznać, że dopiero duchowi Izraelici są rzeczywistym potomstwem Abrahama i dziedzicami powierzonych mu obietnic oraz uczestniczą w udzielonej mu łasce wiary ${ }^{157}$. Dlatego też należą oni już do ekonomii Nowego Testamentu, a zatem i do Chrystusa ${ }^{158}$.

${ }^{145}$ Por. tenże, De civitate Dei XV 17, CCL 48, 479, tłum. Kubicki, s. 574.

${ }^{146}$ Por. tamże XV 18-19, CCL 48, 480-482, thum. Kubicki, s. 575-577.

${ }^{147}$ Por. tamże XV 26, CCL 48, 493, thum. Kubicki, s. 588.

${ }^{148}$ Por. tamże XVI 9-10, CCL 48, 510-511, tłum. Kubicki, s. 605-606.

${ }^{149}$ Por. tamże XVI 32, CCL 48, 536-538, thum. Kubicki, s. 631. Św. Augustyn (De spiritu et littera 31, 54, NBA 17/1, 338, PSP 19/3, 125-126) przywołując postać Abrahama, podkreśla fakt, że jego wiara, która została mu poczytana za usprawiedliwienie, jest darem łaski Bożej. Zasada ta odnosi się również do Izaaka, który jest synem obietnicy oraz do wszystkich członków civitas Dei, gdyż udział w społeczności zbawionych zawsze wymaga łaski Bożej. Por. tenże, De civitate Dei XVI 2-3, CCL 48, 454-456, thum. Kubicki, s. 550-551.

${ }^{150}$ Por. tamże XVI 37, CCL 48, 541-542, thum. Kubicki, s. 635-636.

${ }^{151}$ Por. tamże XVI 43, CCL 48, 548-550, thum. Kubicki, s. 642-644.

${ }_{152}$ Por. tamże XVII 4, CCL 48, 554-555, tłum. Kubicki, s. 649.

${ }^{153}$ Por. tamże XVIII 28-36, CCL 48, 618-632, tłum. Kubicki, s. 717-729.

${ }^{154}$ Por. tenże, Contra Faustum Manichaeum 19, 14, NBA 14/1, 364-366, PSP 55, 197.

${ }^{155}$ Por. tenże, Enarrationes in Ps. 81, 1 CCL 39, 1136, PSP 40, 44-45. Zob. P. Fredriksen, Augustine and Israel: „Interpretatio ad Litteram”. Jews and Judaism in Augustine's Theology of History, StPatr 38 (2001) 133.

${ }^{156}$ Augustinus, Enarrationes in Ps. 75, 1, CCL 39, 1035-1036: „Sunt ergo Iudaei in circumcisione carnis, et sunt Iudaei in circumcisione cordis. Patres nostri multi sancti, et circumcisionem carnis habebant propter signaculum fidei, et circumcisionem cordis propter ipsam fidem. Ab his patribus degenerantes isti qui modo in nomine gloriantur et facta perdiderunt; ab his ergo patribus degenerantes, remanserunt in carne Iudaei, in corde Pagani”, PSP 39, 339.

${ }^{157}$ Por. tenże, De civitate Dei XVII 7, CCL 48, 567-570, tłum. Kubicki, s. 662-663; tenże, Enarrationes in Ps. 134, 7, CCL 40, 1943, PSP 42, 121; tenże, Sermo 4, 11, PL 38, 39; tenże, In Joannis Evangelium tract. 42, 5, CCL 36, 366, PSP 15, 505-506. Zob. B. Blumenkranz, Die Judenpredigt Augustins. Ein Beitrag zur Geschichte der jüdisch-christlichen Beziehungen in den ersten Jahrhunderten, Basel 1946 (Reprint: Paris 1973), 172; C. Mazzucco, Il libro XVI del „De Civitate Dei”, w: Lettura del „De Civitate Dei” Libri XI-XVI, s. 162-170.

${ }^{158}$ Por. Augustinus, De civitate Dei XVII 7, CCL 48, 567-570, thum. Kubicki, s. 662-663. 
Duchowe rozumienie przynależności do Chrystusa, które nie pokrywa się w pełni z granicami widzialnej wspólnoty chrześcijan, oznacza, że mogą istnieć ludzie sprawiedliwi nawet wśród narodów pogańskich. Św. Augustyn, dostrzegając taką możliwość, zalicza do nich przede wszystkim biblijnego Hioba, który nie będąc ani Żydem, ani nawet prozelitą, jest postacią wychwalaną przez Pismo Święte z powodu swej sprawiedliwości i pobożności ${ }^{159}$. Hippończyk zauważa przy tym, że już jeden przykład tego rodzaju człowieka może świadczyć o istnieniu wielu innych sprawiedliwych, którzy nie są objęci zewnętrznymi formami przynależności do wspólnoty zbawionych ${ }^{160}$.

Prymat duchowego wymiaru Kościoła ponad widzialną społecznością zarysowany w idei państwa Bożego posiada jeszcze jedną konsekwencję, niezwykle ważną dla omawianego zagadnienia. Uchwycić ją może spojrzenie na środowisko przeciwstawne wobec civitas Dei. Skoro bowiem duchową Jerozolimę konstytuuje miłość do Boga posunięta aż do zapomnienia o sobie, zaś Babilon jest tworzony przez tych, których miłość siebie prowadzi aż do pogardy Boga ${ }^{161}$, a granice pomiędzy nimi pokrywają się z granicami wyznaczającymi pole zbawienia i potępienia ${ }^{162}$, to można $\mathrm{z}$ całą pewnością uznać, że głównym powodem Bożego gniewu i wiecznej kary jest właśnie pycha. Zaślepieni nią obywatele Babilonu, zamykając się na Boga, nie poprawiają swego postępowania ${ }^{163}$, a to zamknięcie na nawrócenie sprawia, że postępują w swojej złości (malitia) ${ }^{164}$ i sami skazują się na wyrok potępiający ${ }^{165}$.

Jeżeli jednak zamknięta na Boga miłość własna sprowadza na człowieka wieczną karę, to nieuleganie pokusie pychy poprzez zapominanie o sobie dla dobra bliźnich może otwierać możliwość zbawienia także przed ludźmi pozbawionymi łaski wiary, chrztu świętego i przynależności do Kościoła, gdyż ich miłość jest bardzo bliska miłości charakteryzującej mieszkańców duchowej Jerozolimy. Dlatego św. Augustyn zauważa, że również ci z mieszkańców Babilonu, którzy nie poznali Chrystusa mogą być przez Boga zaliczeni do grona obywateli Jerozolimy. Pisze bowiem:

„I to państwo, które nosi nazwę Babilonu, posiada swoich wielbicieli zabiegających o utrzymanie pokoju doczesnego i poza tym nie spodziewających się niczego. Oni to całą swoją radość w tym pokładają i do tego się ograniczają, a widzimy, że dla rzeczpospolitej ziemskiej oni bardzo wiele trudów ponoszą. A także wszyscy, którzy w nim dochowują wierności, nie zostaną z woli

${ }^{159}$ Por. tenże, De peccatorum meritis II 10, 12-14, NBA 17/1, 136-140.

${ }^{160}$ Por. tenże, De civitate Dei XVIII 47, CCL 48, 645-646, thum. Kubicki, s. 744. Zob. J. Pałucki, Trynitarny wymiar Kościoła. Studium patrystyczne, Lublin 2007, 77.

${ }^{161}$ Por. Augustinus, De civitate Dei XIV 28, CCL 48, 451, thum. Kubicki, s. 546.

${ }^{162}$ Por. tenże, De Trinitate XV 18, 32, NBA 4, 680, POK 25, 439.

${ }^{163}$ Por. tenże, Enarrationes in Ps. 100, 13, CCL 39, 1417, PSP 40, 345.

${ }_{164}$ Por. tamże 82, 13, CCL 39, 1145, PSP 40, 55; 117, 7, CCL 40, 1660, PSP 41, 209-210.

${ }^{165}$ Por. tamże 82, 13, CCL 39, 1145, PSP 40, 55; 93, 28, CCL 39, 1329, PSP 40, 252; 100, 13 , CCL 39, 1417, PSP 40, 345. 
Bożej zgubieni w Babilonie, gdyż przez Boga zostali przeznaczeni na obywateli Jerozolimy. Stanie się to jednak pod warunkiem, jeżeli nie będą gonili za przemijającym wyniesieniem i wstrętną chełpliwością, a nade wszystko pychą, natomiast okażą prawdziwą wiarę w miarę możliwości tak długo, jak będą mogli, względem tych, którym będą mogli ją okazywać w zależności od tego jak przedstawiają im się rzeczy ziemskie i rozumieją założenia państwa. Bóg rozumie ich niewolę i pokazał im inne państwo, do którego rzeczywiście powinni wzdychać, któremu powinni poświęcać wszelkie wysiłki i do którego powinni nakłaniać własnych obywateli i współtowarzyszy drogi, żeby razem je zdobyli"'166.

Chociaż ta możliwość zbawienia pogan jest obłożona przez biskupa Hippony wieloma warunkami, to jednak przecież istnieje. Przed tymi zatem, którzy nie należą do instytucjonalnego Kościoła, lecz podejmują wysiłki w służbie dla dobra wspólnego, zapominając przy tym o własnych korzyściach i nie kalając się żadnym występkiem, bramy niebieskiego Jeruzalem stoją otwarte, gdyż służba dla rzeczpospolitej ziemskiej jest dla nich lekarstwem na pychę, a ich trudy domagają się nagrody od Boga ${ }^{167}$.

Podsumowując powyższe analizy, należy zauważyć, że teza o braku możliwości zbawienia poza Kościołem może być potwierdzona lub zaprzeczona w zależności od płaszczyzny rozumienia rzeczywistości Kościoła. Jeśli bowiem rozumie się go jako wspólnotę chrześcijan zjednoczonych ze sobą wiarą w Chrystusa i świętymi sakramentami, to wydaje się, że św. Augustyn widzi możliwość zbawienia ludzi znajdujących się poza nią. W myśli i nauczaniu biskupa Hippony można bowiem znaleźć opisy takich właśnie sytuacji, czego dowodem są jego wypowiedzi o ludziach poświęcających się pracy dla swej ziemskiej ojczyzny, czy też wskazywanie tych, którzy dzięki łasce Bożej są sprawiedliwi i uzyskują zbawienie mimo, że nie należą do widzialnego Kościoła lub też nie otrzymali uświęcenia mocą sakramentów. Jeżeli jednak rozumie się Kościół jako wspólnotę duchową, w której istotną rolę odgrywa miłość do Boga, to teza o niemożliwości zbawienia poza nim daje się w zupełności

${ }^{166}$ Tamże 136, 2, CCL 40, 1964-1965: „Habet et haec civitas quae Babylonia dicitur, amatores suos consulentes paci temporali, et nihil ultra sperantes, totumque gaudium suum ibi figentes, ibi finientes, et videmus eos pro republica terrena plurimum laborare: sed et in ea quicumque fideliter versantur, si non ibi appetant superbiam et perituram elationem odiosamque iactantiam; sed veram fidem exhibeant, quam possunt, quamdiu possunt, quibus possunt, ad quantum vident terrena, et ad quantum intellegunt speciem civitatis; non eos sinit Deus perire in Babylonia: praedestinavit enim eos cives Ierusalem. Intellegit captivitatem eorum Deus, et ostendit illis aliam civitatem, cui vere debeant suspirare, pro qua debeant cuncta conari, ad quam capessendam debeant cives suos secum peregrinos, quantum valuerint, adhortari”, PSP 42, 145. Zob. Bartnik, Augustyńska historiologia, s. 793.

${ }^{167}$ Por. Augustinus, De civitate Dei V 15, CCL 47, 149, tłum. Kubicki, s. 204. 
utrzymać. To bowiem miłość i kierunek zwrócenia serca, jaki ona wyznacza, tworzy granicę pomiędzy Jerozolimą a Babilonem, czyli pomiędzy wspólnotą zbawionych a tymi, którzy skazują się na potępienie.

Należy jednak podkreślić, że duchowy charakter więzi istniejących pomiędzy Chrystusem i Kościołem nie relatywizuje konieczności chrztu świętego do zbawienia, ani też nie czyni łaski Bożej zbędną. Opisane wyżej sytuacje obwarowane są bowiem wieloma warunkami, które sprawiają, że należy uznać, iż zwyczajną drogą udzielania łaski Bożej jest wspólnota sakramentalna. Niemniej jednak istnienie choćby tylko jednego sprawiedliwego poza widzialną społecznością chrześcijan jest znakiem wielkiego Bożego miłosierdzia, które nie zna żadnych granic i każdego człowieka zaprasza do Kościoła - duchowej wspólnoty miłośników Boga.

\section{ABOUT THE POSSIBILITY OF SALVATION OUTSIDE THE CHURCH - SELECTED ISSUES OF SAINT AUGUSTINE'S THEOLOGY}

\section{(Summary)}

In Saint Augustine's teaching, salvation is always an act of God's grace given to man through the agency of Christ. For this reason, the space of granting this grace is the Church, understood as a component of the structure of totus Christus. The Bishop of Hippo stresses, therefore, the need for belonging to the Church and the importance of baptism in the sanctification and salvation of man, because good deeds done without God's grace have no value deserving salvation. The Church is, above all, a spiritual community in which a factor decisive to man's communication with God, besides God's grace, is primarily the love of God; and what closes up the human heart to this grace is pride. Therefore, aside from the visible community of Christians, there are also those just, who are among the saved. They include also those, who cure the disease of pride with the love of other people and service for the common good.

Key words: baptism, the common good, Church, grace, love, city of God, pride, sanctity, faith, salvation.

Słowa kluczowe: chrzest, dobro wspólne, Kościół, łaska Boża, miłość, państwo Boże, pycha, świętość, wiara, zbawienie. 
